\title{
1 Characterisation of coastal counter-currents on the inner shelf of the Gulf of Cadiz
}

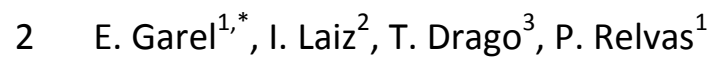

$3 \quad{ }^{1}$ Centre for Marine Sciences (CCMAR), Algarve University, 8005- 139 Faro, Portugal

42 Department of Applied Physics, Faculty of Marine Science and Environment, University of Cadiz, Campus Rio

5 San Pedro, 11510, Puerto Real, Spain

$6{ }^{3}$ Instituto Português do Mar e da Atmosfera (IPMA, I.P.) 1749-077 Lisboa, and Institute Dom Luiz (IDL), FCUL, $7 \quad$ 1749-016 Lisboa

$8{ }^{*}$ Now at Centre for Marine and Environmental Sciences (CIMA), Algarve University, 8005- 139 Faro, Portugal

9 Corresponding author: Erwan Garel (egarel@ualg.pt)

\section{Abstract}

12 At the Gulf of Cadiz (GoC), poleward currents leaning along the coast alternate with coastal 13 upwelling jets of opposite direction. Here the patterns of these coastal countercurrents (CCCs) are 14 derived from ADCP data collected during 7 deployments at a single location on the inner shelf. The multiyear (2008-2014) time-series, constituting 18 months of hourly records, are further analysed together with wind data from several sources representing local and basin-scale conditions. During one deployment, temperature sensors were also installed near the mooring site to examine the vertical thermal stratification associated with periods of poleward flow. These observations indicate that the coastal circulation is mainly alongshore and barotropic. However, a baroclinic flow is often observed shortly at the time of flow inversion to poleward. CCCS develop all year-round and exclusively control the occurrence of warm coastal water during the upwelling season. On average, one poleward flow lasting 3 days was observed every week, corresponding to CCCs during $~ 40 \%$ of the time without seasonal variability. Thus, the studied region is distinct from typical upwelling systems where equatorward coastal upwelling jets largely predominate. CCCs often start to develop near the bed and are frequently associated with 2-layer cross-shore flows characteristic of downwelling conditions (offshore near the bed). In general, the action of alongshore wind stress alone does not justify the development of CCCs. The coastal circulation is best correlated and shows the highest coherence with south-eastward wind in the basin that proceed from the rotation of southward wind at the West coast of Portugal, hence suggesting a dominant control of large-scale wind conditions. In agreement, wavelet analyses indicate that CCCs are best correlated with alongshore wind occurring in a band period characteristic of the upwelling system (8-32 days). Furthermore, in the absence of wind coastal currents tend to be poleward during summer. This set of observations supports that CCCs develop in response to the unbalance of an alongshore pressure gradient during the relaxation of (system-scale) upwelling-favourable winds, oriented southeastward in the basin. The relaxation periods defined based on this wind direction show a good correspondence with the periods of poleward flow.

\section{Keywords}


Coastal countercurrents; Upwelling; Wind-driven currents; Shelf dynamics; Relaxation; South-west Iberia; Gulf of Cadiz.

\section{Introduction}

Poleward currents leaning along the coast are characteristic features of Eastern Boundary Upwelling Systems (EBUS). These flows alternate with the predominant coastal upwelling jets of opposite equatorward direction, and are as such commonly referred to as "coastal countercurrents" (CCCS). The occurrence of CCCs has been reported in major coastal upwelling systems, in particular along the Gulf of Cadiz (GoC, Southern Iberia) in the Portuguese-Canary Current upwelling system (Mittelstaedt, 1991; Pelegrí et al., 2005a; Pelegrí et al., 2005b; Relvas and Barton, 2002), over the Namaqua shelf (South Africa) in the Benguela Current upwelling system (Fawcett et al., 2008), and in the northern (Kosro, 2005; Largier et al., 1993; Lentz and Chapman, 1989; Send et al., 1987; Winant et al., 1987), central (Harms and Winant, 1998; Melton et al., 2009; Washburn et al., 2011; Woodson et al., 2009) and southern (Dever, 2004; Winant et al., 1999; Winant et al., 2003) portions of the California Current upwelling system. Typically, 10 to $30 \mathrm{~km}$-wide CCCs advect warm water previously retained in the lee of capes or embayments during active upwelling and temporarily displace the previously upwelled colder water offshore (Send et al., 1987). This process causes rapid temperature changes over the inner shelf (Melton et al., 2009; Relvas and Barton, 2002). In addition, CCCs may affect ecosystems with the transport of waterborne material such as pollutant and larvae into nearshore areas, where many subtidal and intertidal species settle (e.g., Dudas et al., 2008; Mace and Morgan, 2006; Wilson et al., 2008; Wing et al., 1995).

Most of the studies about the characteristics and forcing mechanisms of CCCs have been conducted at the California Current upwelling system, based on very extensive sets of hydrographic observations across and along the inner shelf, completed with wind data from buoys and coastal stations. Examples include the CODE experiments and the multiyear Santa Barbara Coastal Long-Term Ecological Research (SBCLTER) project (Melton et al., 2009; Washburn et al., 2011). A major result from these observations was the establishment that CCCs are driven by poleward alongshore pressure gradients (APGs) that result from differences in sea level along the coast. Large scale alongshore sea surface slopes are produced between coastal headlands by the persistence of equatorward (upwelling favourable) winds (Largier et al., 1993; Winant et al., 1987; Winant et al., 2003). Numerical studies have further indicated that interactions between coastal upwelling jets and alongshore variations in the coastline and shelf bathymetry promote the development of smaller scale poleward APGs in the lee (i.e., equatorward) of capes and promontories (Gan and Allen, 2002). CCCs are triggered when these large- or small- scale APGs become 
unbalanced during wind relaxation events; these are defined as the weakening or even reversal of usually strong upwelling favourable winds (Huyer and Kosro, 1987).

In contrast with the Californian inner shelf, few studies have been devoted to the coastal circulation in the GoC. Until now, most of these works dealt with remotely sensed seasurface temperature (SST) or climatological data (Fiúza, 1983; Fiúza et al., 1982; Folkard et al., 1997; Sánchez and Relvas, 2003; Vargas et al., 2003). The few hydrodynamic observations performed on the inner shelf with fixed stations (Lobo et al., 2004; Sánchez et al., 2006) or shipboard surveys (García-Lafuente et al., 2006) were of short duration (less than 1 month), with the exception of a multiyear $(2002,2004,2005)$ current time-series used to examine the surface circulation at the seasonal and inter-annual time-scales (Criado-Aldeanueva et al., 2009). However, there is so far no detailed study based on longterm observations dealing with current inversions at an "event scale" for the definition of the patterns of poleward flows (e.g., duration and frequency) and their relation with wind conditions. Consequently, the CCCS patterns in this region and their driving processes are not clear yet. Based on SST satellite imagery, coastal wind and tidal gauges data, Relvas and Barton (2002) proposed that CCCs are driven by a background APG, similar to the situation along the Californian coast. Other processes that have been proposed for the production of an APG in southern Iberia include exchanges through the Strait of Gibraltar (Mauritzen et al., 2001), the effects of large-scale atmospheric pressure systems (Sánchez et al., 2006), and tidal advection of warmer (hence lighter) coastal water from the numerous shallow inland areas located in the Eastern GoC (García-Lafuente et al., 2006). Numerical studies also suggest that CCCs are produced in response to the action of wind stress alone, rather than to the relaxation of upwelling favourable wind (Teles-Machado et al., 2007). This latter hypothesis does not require a background APG for the development of CCCs.

The present research compiles 7 Acoustic Doppler Current Meter (ADCP) deployments of about 1 to 3 months duration at a single location on the inner shelf of the GoC. This dataset is used to characterise the dynamics of CCCs from an Eulerian perspective, with the aim of contributing to untangle the mechanisms that drive these currents in the region, including their connection with the offshore circulation. In particular, it is verified whether the action of wind stress alone is able to account for the observed periods of poleward flows.

\section{Region of study}

The GoC is the wide embayment of the Atlantic Ocean that constitutes the equatorward extremity of the Iberian upwelling system. The northern margin of the GoC stretches along the south-western Iberian Peninsula from Cape St Vicente (CSV, southwest Portugal) to the western side of the Strait of Gibraltar (Figure 1). Cape Santa Maria (CSM) divides the continental shelf (approximately bounded by the $150 \mathrm{~m}$ isobath) into two halves with distinct morphological settings. West of CSM the shelf is narrow $(<15 \mathrm{~km})$ and incised with various canyons; to the East, it is steep and narrow $(<5 \mathrm{~km}$ ) near CSM, but quickly widens (> 
$11340 \mathrm{~km}$ ) eastward with a gentle slope. These characteristics may create a distinct and 114 independent water circulation over the eastern and western regions (Criado-Aldeanueva et 115 al., 2009; García-Lafuente et al., 2006).

116 The upwelling season of the Iberian upwelling system is well-defined between April and 117 October (Fiúza et al., 1982; Haynes et al., 1993; Peliz and Fiuza, 1999; Wooster et al., 1976), 118 based on highly contrasted seasonal wind regimes associated with the zonal displacement 119 of the Azores high- and Icelandic low-pressure systems. During the upwelling season, strong 120 northerly winds blow along the West coast, while westerlies and southwesterlies prevail in 121 winter. Northerlies rotate counter clockwise around CSV and blow south-eastward off 122 southern Portugal, due to the establishment of a low pressure centre over the Iberian 123 Peninsula in summer, together with orographic constraints (Relvas and Barton, 2002).

124 Although included in the Canary Current Upwelling System (CCUS), the eastern boundary 125 discontinuity imposed by the entrance to the Mediterranean Sea modifies the Canary 126 Current upwelling regime prevailing at the GoC. Typically, the Iberian upwelling system is 127 associated with equatorward coastal flows (i.e., southward and eastward along the West 128 and South coasts, respectively) of cool water forced by geostrophic adjustment. East of CSV, 129 however, the coastal jet proceeds from the one affecting the West coast, and its 130 propagation along the South coast depends on the local wind conditions, with westerlies 131 and easterlies promoting and hampering its poleward extension, respectively (Fiúza, 1983; 132 Fiúza et al., 1982; Folkard et al., 1997; Sánchez and Relvas, 2003). Westerlies also tend to 133 produce a secondary upwelling core immediately east of CSM that may merge with the 134 more permanent core off CSV. Overall, while the upwelling regime is quasi-permanent in 135 summer at the West coast, the intensity and occurrence of upwelling events at the South 136 coast is significantly reduced, in particular towards the Eastern GoC, as reported by Relvas 137 and Barton (2002) based on the analysis of a multiyear dataset of SST images. These data 138 further show that the coastal circulation during summer along the South coast is rather 139 dominated by the alternation of equatorward (i.e., eastward) upwelled water and a 140 poleward (i.e., westward) warm flow (CCC) propagating from the eastern GoC. In their 141 detailed study based on cloud-free satellite images available mostly during the summer 142 months, Relvas and Barton (2002) have noted the presence of warm CCC during $45 \%$ of the 143 time at the South coast. These flows were associated with temperature increases, reaching 144 more than $5^{\circ} \mathrm{C}$ in some cases. The coastal tongue of warm water is typically about $10-15 \mathrm{~km}$ 145 wide, with an estimated velocity around $0.2 \mathrm{~m} \mathrm{~s}^{-1}$ that has been confirmed by direct 146 measurements in summer (García-Lafuente et al., 2006) and winter (Sánchez et al., 2006). 147 Based on cross-shore ship measurements, García-Lafuente et al. (2006) have suggested that 148 the CCC is a stable feature in summer, being the northern boundary of a cyclonic cell located 149 on the eastern shelf between CSM and the mouth of the Gualdalquivir Estuary (for location, 150 see Figure 1). In any case, the propagation of poleward currents depends on local wind 151 conditions (Fiúza, 1983; Folkard et al., 1997; Relvas and Barton, 2002). García-Lafuente et al. 152 (2006) have further proposed that westward blowing wind is required for the coastal 
current to pass over CSM. In extreme cases, CCCs may reach CSV and extend more than 100 $\mathrm{km}$ northwards along the West coast (Relvas and Barton, 2002). SST images in winter also show the occurrence of CCCs associated with a cold water signature along the coast. The presence of a pool of cold water on the eastern GoC in winter has been attributed to freshwater advection from the large rivers of this coastal sector (Peliz et al., 2004).

\section{Data and Methods}

3.1. Data

Current velocities along the water column and near-bed temperature were collected with an Acoustic Doppler Current Profiler (ADCP Workhorse $600 \mathrm{kHz}$, TRDI). The instrument was bottom-mounted 7 times between 2008 and 2014 at a single location $\left(37^{\circ} 0.648^{\prime} \mathrm{N} ; 7^{\circ}\right.$ $44,480^{\prime} \mathrm{W}$ ) on the inner shelf of the GoC, at $23 \mathrm{~m}$ water depth east of CSM (Figure 1). The deployments were performed during various periods of the year and for durations ranging from 40 to 133 days (Table 1). The instrument was installed inside the upper part of an artificial reef at $1.40 \mathrm{~m}$ from the bed. Various instrument configurations were used for each deployment, as the main objective was not always the study of the coastal water circulation. Velocity ensembles were recorded within cells of 0.5 or $1 \mathrm{~m}$ in thickness, every 5 to $60 \mathrm{~min}$. The uncertainty (standard deviation) of the measured velocities was generally less than $0.015 \mathrm{~m} \mathrm{~s}^{-1}$. In total, the dataset contains 598 days of hourly records (Table 2). Observations were mostly performed from May to December ( $>1,000 \mathrm{hr}$ each month); they were comparatively fewer in January, February and April, and no data were collected in March (Table 2). Despite this uneven temporal distribution, the seasonal variability of poleward flows can be examined through the comparison of the months of June to August and of November to January. For these months, the summer and winter seasons are wellestablished, hence avoiding transitory months that may smooth the results of seasonal comparisons. In addition, a large and similar number of current observations are available for these 2 contrasted periods (see Table 2).

Hourly wind data were obtained from the Cadiz offshore buoy, located over the $450 \mathrm{~m}$ isobath at $90 \mathrm{~km}$ from the mooring site (Figure 1). Due to its offshore location, this buoy is generally considered as representative of the wind conditions in the eastern GoC (CriadoAldeanueva et al., 2009; Criado-Aldeanueva et al., 2006; García-Lafuente et al., 2006). In the present paper, wind direction follows the oceanographic convention (the wind direction is where the wind is blowing) to ease comparisons of wind and current data. Wind conditions during the deployments were typical of the seasonal wind regime in the basin (Figure 2). In particular, while the wind velocity was mild and principally blowing south-eastward in JuneAugust (Figure 2b), velocities were stronger with larger occurrences of westward to southward winds in November-January (Figure 2c). 
Additional wind sources located near the mooring site were also considered to examine whether the local wind is more able to account for the development of CCCs than the basinscale wind from the Cadiz buoy. These sources include (for location, see Figure 1): a coastal station (Tavira) providing observations every 10 to $30 \mathrm{~min}$; a mesoscale atmospheric model of $15 \mathrm{~km}$ resolution (HIRLAM) with outputs at 1 to $3 \mathrm{hr}$ intervals; and remotely-sensed wind from daily passes of a satellite scatterometer (ASCAT). Wind data at Tavira station were not available for deployments 6 and 7; likewise, ASCAT data for deployment 7.

A thermistor chain with 3 temperature-depth (TD) sensors (Star-Oddi, DST centi-TD) was deployed from the $5^{\text {th }}$ of August to the $5^{\text {th }}$ of November 2014 (i.e., spanning the entire Deployment 6), at $100 \mathrm{~m}$ from the ADCP mooring site. The sensors were mounted along a rope fixed at the bottom and maintained vertical with a small surface buoy, providing hourly records at $\sim 7 \mathrm{~m}, \sim 13 \mathrm{~m}$ and $\sim 18 \mathrm{~m}$ water depths.

\subsection{Processing}

The ADCP data, collected at various time intervals, were ensemble averaged at a one hour interval. The cells located above $10 \%$ of the total pressure depth, and the cell immediately below, were discarded due to side lobe interferences at the surface boundary. Furthermore, cells having at least 3 of the 4 beams with a correlation magnitude less than 64 counts, and those having 2 or more beams with a vertical difference greater than 30 counts were invalidated. Ensembles with at least 1 invalidated cell were also discarded. Validated velocity data were then vertically interpolated every $50 \mathrm{~cm}$ at a range extending from $2.2 \mathrm{~m}$ from the ADP head ( $3.6 \mathrm{~m}$ from the bed) up to the last valid cell near the surface boundary. The east- and north-velocity components were rotated into along- and cross-shore components according to the angle of maximum variance. The latter was computed separately for each deployment to account for potential variability in the flow direction. The flow was however essentially parallel to the shore during the 7 deployments, ranging from $37^{\circ} \mathrm{E}$ (counter-clockwise from East, hereafter) to $31^{\circ} \mathrm{E}$ in 2010 and 2013, respectively. For each ensemble, depth-averaged velocities of the cross-shore and along-shore components were computed as the mean velocity.

Wind data from the Cadiz offshore buoy are measured at an elevation of $3 \mathrm{~m}$ from the sea surface; they were reduced to a height of $10 \mathrm{~m}$ using a power law profile with a Hellman exponent of 0.11 representing typical open water conditions. The data from the other wind sources were already measured or reduced at $10 \mathrm{~m}$ height. The Cadiz buoy was not transmitting from the $6^{\text {th }}$ of December 2014 to the $14^{\text {th }}$ of March 2015. The corresponding data gap (at the end of deployment 7) was filled up with data from the HIRLAM model. For each deployment period, wind velocities were interpolated and rotated in along- and crossshore components, using the same time ( $1 \mathrm{hr}$ interval) and angles of variance than those considered for the ADCP data. The wind stress was then computed according to Large and Pond (1981). 
In order to remove tidal and other higher frequency oscillations, all the (current, wind and

228 temperature) time-series were low-passed filtered using a Butterworth filter with a 40h cutoff period. Every reference to the data hereafter applies to the low-pass filtered time-series, unless stated otherwise. Likewise, equatorward and poleward flows refer to depth-averaged alongshore currents oriented north-eastward and south-westward, respectively, along the studied coastal stretch. Similarly, poleward wind indicates alongshore wind blowing towards the western GoC. The term "inversion" is exclusively used to describe the reversal of alongshore flows from equatorward to poleward (i.e., the development of CCCs). CCC (or poleward flow) events refer to the periods when these flows are observed continuously. Finally, "winter" and "summer" strictly refer to the months of June-August and NovemberJanuary, respectively (transitory months being the other months), except where indicated.

\section{Observations of poleward flows}

\subsection{General CCC patterns}

240

Alongshore current direction varies at a time scale of about 4 days, on average, at the mooring site (Figure 3a). Maximum equatorward and poleward values are up to $\sim 0.4 \mathrm{~m} \mathrm{~s}^{-1}$.

242 The mean velocity of CCCs and equatorward flows was $0.12 \mathrm{~m} \mathrm{~s}^{-1}$ and $0.16 \mathrm{~m} \mathrm{~s}^{-1}$, respectively. Both flows have a distinct signature: equatorward flows often stabilise near maximum values during few days before decreasing, outlining a rectangular-shaped positive curve; CCCs are characterised by short peaks of maximum velocities, resulting in a spiky negative velocity time-series. The maximum depth-averaged poleward current velocity of the non-filtered time-series was $0.52 \mathrm{~m} \mathrm{~s}^{-1}$ on the $11^{\text {th }}$ of December 2013 (not shown).

CCCs are frequently observed ( $42 \%$ of the time), with no significant difference between the summer $(41 \%)$ and winter months (43\%; Table 2). In total, 82 current inversions were observed, with 4 and 3.3 inversions per month in summer and winter, respectively (Table 2). The longest CCC event lasted $\sim 15$ days, from the $23^{\text {rd }}$ of November to the $8^{\text {th }}$ of December 2013 (Figure 4a). In summer, the longest CCC event was $\sim 9$ days from the $29^{\text {th }}$ of August to the $7^{\text {th }}$ of September 2010. Overall, the mean duration of these events was 2.9 days, with no clear seasonal trend (3.4 and 3.2 days in winter and summer, respectively; Table2; see also red line in Figure 4a).

256 On average, CCCs were stronger in winter $\left(0.09 \mathrm{~m} \mathrm{~s}^{-1}\right)$ than in summer $\left(0.05 \mathrm{~m} \mathrm{~s}^{-1}\right)$ due to the 257 occurrence of westward winter storms. An opposite pattern was observed for the mean equatorward flow, being $0.07 \mathrm{~m} \mathrm{~s}^{-1}$ in summer and $0.03 \mathrm{~m} \mathrm{~s}^{-1}$ in winter. Peak CCC velocities were also generally larger in winter (in particular, in December) than in summer (see red line in Figure 4b). As an example, 39\% of the CCC events in winter reached velocities $>0.25 \mathrm{~m} \mathrm{~s}^{-}$

261 , but only $23 \%$ in summer. Yet, the maximum velocity of poleward flows may occasionally 262 be as large in summer as in winter (Figure $4 \mathrm{~b})$. In fact, the largest velocity $\left(0.41 \mathrm{~m} \mathrm{~s}^{-1}\right)$ of the 
263 entire time-series was on the $8^{\text {th }}$ of August 2010 during an event lasting 8.5 days (Figure 3a;

264 Figure 4b).

265 Overall, there is a broad positive correlation between the duration of the CCC events and 266 the associated peak velocity (Figure 5), as pointed out by the similar variation of the 267 monthly averaged lines in Figures $4 a$ and $4 \mathrm{~b}$. A linear (or nearly linear) correlation is 268 conspicuous for peak velocities $<0.2 \mathrm{~m} \mathrm{~s}^{-1}$ and duration $<\sim 4$ days. Generally, CCC events 269 were long and strong in winter and summer, and short and weak during transitory months 270 (Figure 5).

271 The cross-shore flow component is one order of magnitude lower than the alongshore 272 component, rarely exceeding $0.04 \mathrm{~m} \mathrm{~s}^{-1}$ (Figure $3 \mathrm{~b}$ ). This confirms that the coastal 273 circulation is essentially parallel to the coastline in the region. More specifically, the cross274 shore flow is predominantly landward (71\% of occurrence during the entire observation 275 period), with no seasonal differences: landward flows were observed $69 \%$ and $67 \%$ of the 276 time in summer and winter, respectively. Cross-shore flows were however more often 277 onshore at the time of poleward flow (75\%) than equatorward flows (67\%). The 278 development of CCCs is often associated with sharp peaks of offshore velocities up to 0.05 $279 \mathrm{~m} \mathrm{~s}^{-1}$, such as on the $29^{\text {th }}$ of April 2014 and $20^{\text {th }}$ of November 2014 (Figure 3b). These peaks 280 result from small veering clockwise of (still strong) alongshore current at the start of 281 inversions.

\subsection{CCCs and temperature}

283 Near bed temperatures from the ADCP varied between $13^{\circ} \mathrm{C}\left(30^{\text {th }}\right.$ of May 2014) and $23.5^{\circ} \mathrm{C}$ 284 (16 ${ }^{\text {th }}$ of September 2010 ), exhibiting a strong seasonal variability (Figure 3c). During the non285 upwelling season, the water temperature at the study site was less than $16^{\circ} \mathrm{C}$ and slowly 286 varying, with the coldest value in February $2014\left(13.15^{\circ} \mathrm{C}\right)$. During the upwelling season, the 287 temperature was highly variable and ranged between $14^{\circ} \mathrm{C}$ and $24^{\circ} \mathrm{C}$. The overall 288 temperature pattern is consistent with the North Atlantic seasonal cycle, with the higher 289 variability attributed to the occurrence of upwelling events.

290 During the upwelling season, the development of poleward (equatorward) flows was always 291 associated with temperature increases (decreases), although sometimes small (e.g., $<1^{\circ} \mathrm{C}$ 292 for the weakest events). The most pronounced temperature rise was $6^{\circ} \mathrm{C}$ in only 3 days, 293 during a CCC event peaking up to $0.32 \mathrm{~m} \mathrm{~s}^{-1}$ (September 2010, Deployment 3 on Figure 3). 294 Similar sharp temperature increases associated with strong CCC events were observed in 295 the summers of 2008 (Deployment 1) and 2014 (Deployment 5; Figure 3). Due to the 296 advection of warm water by the poleward flow, the distribution of temperature is skewed 297 toward higher values (Figure 6). Clearly, CCCs control the occurrence of warm water during 298 the upwelling season. Considering only the summer months (June-August), a linear relation $299\left(\mathrm{dT}=12 \mathrm{u}_{\max }\right)$ is found between the temperature increase (dT, computed as the difference 
between maximum and minimum temperature values) and peak velocity ( $\left.u_{\max }\right)$ during poleward flow events, with a correlation coefficient (r) of 0.89 (Figure 7).

During the non-upwelling season, CCCs are associated with small temperature changes (increase or decrease, if any), generally $<1^{\circ} \mathrm{C}$ (see for example December 2010 and 2014 on Figure 3 ) due to the homogenization of the temperature gradients during winter.

\subsection{Vertical structure of CCCS during the thermistors deployment}

Several current reversals were recorded during the thermistors deployment in summer 2014 (Figure 8a, where poleward flows are contoured in blue). As previously observed, all $\mathrm{CCC}$ events were associated with temperature increases (from $<1^{\circ} \mathrm{C}$ to $>5^{\circ} \mathrm{C}$ ), with larger changes corresponding to stronger velocities. The arriving of warm water was accompanied with an increase of thermal stratification along the water column (Figure 8c). This is wellevidenced by the temperature records from the 2 sensors nearest to the bed, which differ only during poleward flow events (e.g., $19^{\text {th }}$ to $22^{\text {nd }}$ of August and $03^{\text {rd }}$ of September in Figure 8). A 2-layer alongshore flow was often observed at the time of inversions with the flow reversal first occurring near the bed (see the leftward slope of the thick contour separating equatorward and poleward flows in Figure 8a). However, the temperature near the surface increased generally earlier than near the bed (Figure 8c). In some cases, the near surface temperature often started to increase while the flow was still equatorward (see the example denoted with arrows in Figure 8).

As noted previously (Figure $3 \mathrm{~b}$ ), inversions were associated with pulses of offshore flows due to small currents meanders, which were also observed during the thermistors deployment (see the dark blue areas in Figure 8b). The pulses appear along the entire water column, indicating that the flow veers barotropically. Once the CCCs had developed, a relatively vigorous 2-layer flow was generally established (during the temperature rise), with offshore velocity near the bed and onshore velocity near the surface, characteristic of downwelling conditions (Figure $8 \mathrm{~b}$ ). This is for example the case after the inversion indicated with an arrow or after the first inversion ( $7^{\text {th }}$ of August) in Figure 8.

\section{4. $\quad$ Alongshore wind stress and poleward flow}

During the upwelling season, the alongshore wind stress at Cadiz buoy was low (generally < $0.05 \mathrm{~N} . \mathrm{m}^{-2}$ ) and predominantly eastward (Figure $3 \mathrm{~d}$ ). In contrast, the non-upwelling season was characterised with the frequent occurrence of gales in both the eastward and westward directions, while periods with weak wind stress $\left(<0.05 \mathrm{~N} . \mathrm{m}^{-2}\right)$ rarely exceeded a week. These differences in the alongshore wind stress reflect typical seasonal changes of wind regime in the basin. Indeed, during the non-upwelling season winds are not only stronger but also more parallel to the alongshore direction than during the upwelling season (see Figure 2). These seasonal patterns are not associated with similar variations in the magnitude of alongshore currents (Figure 3). Westward storms clearly correspond to large 
poleward flow velocities (e.g., November 2010) and to long CCC events (e.g., November 2013). Nevertheless, these relations are not always observed. For instance, no inversion was observed during the short gale of November 2008 with westward alongshore wind stress exceeding $0.2 \mathrm{~N} . \mathrm{m}^{-2}$ (Figure 3).

The periods of poleward wind from various sources and poleward flow were plotted together along the time-axis to verify their overall temporal correspondence (Figure 9). The red horizontal lines represent the periods with poleward flows. These (red) lines are superimposed to thicker lines indicating the periods with poleward wind at the atmospheric model (HIRLAM, upper, blue), satellite observations (ASCAT, grey), the coastal station (Tavira, green) and the offshore buoy (Cadiz, blue). The lower (black) line denotes relaxation periods discussed in Section 5.4. At first glance, the red and thicker lines roughly correspond, indicating that CCCs generally occurred at approximately the same time as poleward wind at all the sources. The percentage of time with combined poleward flow (> $0.1 \mathrm{~m} \mathrm{~s}^{-1}$ ) and poleward wind is also indicated in Figure 9. The percentage of time with combined poleward flow $(>0.1 \mathrm{~m} / \mathrm{s}$ ) and poleward wind is also indicated in Figure 9. This percentage is largest for Cadiz and ASCAT (65\%), followed by HIRLAM (62\%); Tavira station shows a much lower score (50\%). This confirms that it is reasonable to consider Cadiz buoy data as the most representative of the wind conditions affecting water circulation in the basin, in agreement with previous studies (Criado-Aldeanueva et al., 2009). Interestingly, HIRLAM and ASCAT data can also be useful, while coastal stations should be discarded most probably because of land effects. Looking into more details, the lag of CCC in relation to poleward wind (at Cadiz) was computed considering only the events that could be clearly identified (i.e., a single CCC event associated to a single poleward wind period) and with a maximum lag of 3 days (although the latter conditions did not affect the overall results). On average, inversions occurred 18 hours after the set up of poleward wind; likewise, flow reversal to equatorward occurred 23 hours after the wind (for example, see the events annotated 'lag' below Cadiz line in Figure 9). This indicates that alongshore flows reverse more easily from equatorward to poleward than the opposite in response to local or basinscale wind. In addition, several CCC events were not associated with poleward wind at any source (see for example the events annotated ' $x$ ' in Figure 9). Inversely, numerous periods of westward wind at all the sources were not associated with poleward flows (for example, see the events annotated 'o' in Figure 9).

When looking at specific events, a good match was sometimes observed between CCCs and wind from all sources (e.g., October 2008 and November 2010 in Figure 10a, b). In these examples, the inversion lags the setup of poleward wind, as previously observed (e.g., 'lag' in Figure 9). However, for a number of reversals, current and wind displayed markedly different patterns. In some cases, the inversion occurred before the wind from all sources blew poleward (for example, see $1^{\text {st }}$ of December 2008, $23^{\text {rd }}$ of November 2010 and $7^{\text {th }}$ of December 2010 in Plate 1 provided as supplementary material). Furthermore, there were some relatively long periods with large poleward wind speeds at all sources which were not 
377 associated with CCCs but rather with a relatively strong equatorward flow (e.g., $22^{\text {nd }}$ of 378 January 2014 in Figure $10 d$; see also $26^{\text {th }}$ of November 2008 and $23^{\text {rd }}$ of January to $3^{\text {rd }}$ of 379 February 2014 in Plate 1). Inversely, inversions occurred while none of the winds from the 380 distinct sources was blowing poleward (e.g., May 2008 in Figure 10c; see also $6^{\text {th }}$ of 381 November 2010, 30 ${ }^{\text {th }}$ of October 2010 and $22^{\text {nd }}$ of June 2014 in Plate 1).

\section{Discussion}

\subsection{Dynamics of CCCS}

384

385

386

387

388

389

390

391

392

393

394

395

396

397

398

399

400

401

402

403

404

405

406

407

408

409

410

411

412

413

CCCS are common features of EBUS. Although they have been recognised in all major systems, they have been mostly characterised along the Californian coast (e.g., Send et al., 1987). Of particular interest is the Santa Barbara Channel (SBC), which shares similar coastline configuration with the GoC northern margin. The main geographical differences between both regions are the discontinuity imposed by the Strait of Gibraltar at the GoC and the existence of the Channel Islands at the SBC. CCCs velocities reported in the SBC are of similar order of magnitude than those documented here and in previous studies at the GoC (García-Lafuente et al., 2006; Sánchez et al., 2006). For example, Melton et al. (2009) reported poleward subtidal velocities of up to $0.5 \mathrm{~m} \mathrm{~s}^{-1}$, corresponding to a propagation speed of 10-30 km day ${ }^{-1}$. Similar velocities were also reported along the northern California shelf (Send et al., 1987). Poleward flows are observed all year-round the GoC and SBC. However, CCCs may advect warm water in the winter season at the SBC but not at the GoC. This is probably because the $\mathrm{GoC}$, contrarily to the $\mathrm{SBC}$, has large rivers on the eastern side of the bight that discharge cold water during winter, particularly between November and March (Navarro and Ruiz, 2006).

While no seasonal pattern was identified at the GoC, CCCs are more frequent from March to November in the SBC and less frequent in December-January (Melton et al., 2009). This result at the SBC was obtained without considering inversions during winter storms, as the study focused on wind relaxation events. In contrast, the present study considered all periods of poleward flow for the general characterisation of these currents. With storms defined as events with alongshore wind velocities $>7 \mathrm{~m} \mathrm{~s}^{-1}$ (corresponding to a stress of $0.068 \mathrm{~N} . \mathrm{m}^{-2}$ ), about half of the inversions in winter occurred during storms, while no storms took place in summer. If winter storms are discarded, the number of inversions would therefore be larger in summer than in winter, as at the SBC. Note however that inversions occurring during winter storms might still develop primarily in response to a wind relaxation process.

Similar to the SBC, current inversions are mainly barotropic at the GoC, but tend to start near the bed (Figure 8). To examine the dynamics of these events, a principal component analysis (PCA) was applied to the alongshore velocity time series in order to separate the barotropic flow from the 2-layer baroclinic flow (see Garel and Ferreira, 2013; Stacey et al., 

$\mathrm{m}$ from the bed, with a PC1 that was the barotropic velocity profile and a PC2 that was a 2layer flow. Results are consistent between each deployment and are only shown for the thermistors deployment together with examples of the vertical alongshore flow structures of PC1 and PC2 at selected times (Figure 11, where CCC events are outlined with grey boxes). The PCA analysis confirms that the alongshore flow is largely barotropic, with PC1 defining $98.08 \%$ of the total variance (Figure 11c and e), while PC2 defined almost all (1.74 $\%)$ the remaining variance. This is in agreement with the essentially unidirectional flow observed in Figure 8a. The examples (Figure 11f, g) are provided at times when PC2 is peaking, hence showing a well-developed baroclinic flow along with the barotropic component. Note however that these specific cases should not be considered as representative of the typical contribution of PC1 and PC2 to the overall variability. The largest peaks of energy (square of velocity) of PC1 often correspond to CCC events (Figure 11a), as poleward flows generally reach larger velocities than equatorward flows; this is related to the previously described "spiky" and "plateau-like" pattern of poleward and equatorward flows, respectively. PC2 energy is one order of magnitude lower than PC1

430 energy, and displays also commonly large peaks in association with poleward flows (Figure 11b). As observed previously (Figure 8a), these peaks occur predominantly - but not only near the start and end of CCC events (Figure 11b) at times of strong current acceleration or deceleration. Considering the whole time series, the near-bed PC2 is poleward $50 \%$ of the time, and slightly more during poleward flows (54\% of the time). Considering a time window of $4 \mathrm{hr}$, centred on the time of current reversal, $62 \%$ of the near-bed PC2 is poleward at the start of CCC events, and only $29 \%$ at the end. This indicates that, very generally, the baroclinic flow tends to be equatorward near the surface and poleward near the bed during inversions; likewise, the flow is poleward near the surface and equatorward near the bed during the reversal to equatorward. Yet, the overall contribution of the baroclinic flow on the total flow is generally negligible, as illustrated by the high similarity between PC1 and the observed flow (Figure 11c, e). The baroclinic flow component may account for a significant part of the total flow only when the barotropic flow is very weak. Under these conditions, a 2-layer flow might develop, as observed in Figure 8 and exemplified in Figure $44411 \mathrm{~g}$. Note that the latter example corresponds to the baroclinic events denoted with arrows 445 in Figure 8.

446 At the SBC inner shelf (15 m water depth), the arrival of warm water is associated with the development of a 2-layer cross-shore flow directed onshore near the surface, typical of downwelling conditions (Melton et al., 2009). The alternation of upwelling-downwelling cycles allow onshore-offshore exchanges of nutrients and other water-borne material, and are as such essential to support near-shore ecosystems (Washburn and McPhee-Shaw, 451 2013). In the present study, a 2-layer cross-shore flow was also observed during the 452 thermistors deployment (Figure 8b), with blue areas (offshore flow) near the bed generally 453 topped by red areas (onshore flow). This baroclinic flow was clearly stronger during CCC 
events (the darkest red and blue areas in Figure $8 \mathrm{~b}$ correspond to poleward alongshore flow denoted in blue in Figure 8a). Hence, the previously described PCA method was applied to the cross-shore flow to analyse the development of the baroclinic and barotropic flows during CCC events. Like for the alongshore flow, the results are consistent between deployments and have only been represented at the time of the thermistors deployment (Figure 12). The dataset is dominated by PC1, which defined $67 \%$ of the variance; PC2 defined a large part (26\%) of the remaining variance. Examples of the contributions of PC1 and PC2 to the measured profile are shown in Figures $11 \mathrm{~g}$ and $\mathrm{h}$. The largest peaks in energy of both PC1 and PC2 were associated with CCCs. The PC1 peaks correspond to the previously mentioned small veering of the alongshore flow at current inversions (e.g., Figure $12 \mathrm{~h}$, corresponding to the event annotated with arrows in Figure 8). PC2 energy peaked mostly during CCCs events (annotated with grey boxes in Figure 12). In details, the PC2 associated with poleward flows is mainly offshore near the bed (figure 12d), hence onshore near the surface, typical of downwelling conditions. Overall, offshore near-bed PC2 occurred $50 \%$ of the time considering the whole time series, but $70 \%$ of the time during CCC events. This set of observations indicates that poleward flows tend to be accompanied with the intensification of the cross-shore baroclinic circulation depicting predominantly downwelling conditions (e.g., Figure 12g). Further studies are required to study the effect of these flows on the exchanges between the coastal and open sea areas.

\subsection{Linkage between CCC and open sea circulation}

Previous studies at the GoC based on current observations have proposed that the shelf circulation is cyclonic in spring-summer and anticyclonic in autumn-winter due to strong coupling to the open sea circulation, the latter being forced by the seasonal wind regime in the basin (Criado-Aldeanueva et al., 2009; García-Lafuente et al., 2006). In this view, the inner shelf circulation is predominantly poleward in spring-summer, when wind blows mainly south-eastward, and equatorward in autumn-winter. This pattern is not clear in the (single) multiyear current time-series on the shelf that was available before the present study, which rather displays large seasonal and inter-annual fluctuations (see Figure 5 in Criado-Aldeanueva et al., 2009). Besides, our observations indicate that CCCs occur $\sim 42 \%$ of the time, with no significant variations between summer and winter, and were generally associated with poleward rather than equatorward wind in the basin (Figure 9). To detail this distribution, occurrences of CCCs in July, August, November and December are reported in Table 3 on a yearly basis. During these months, the open sea water circulation is the strongest and coastal flow predominance should be the most pronounced (CriadoAldeanueva et al., 2009). However, our data indicate that equatorward flows rather than CCCs generally prevailed in July-August, with the exception of August 2010. In NovemberDecember, equatorward flows were only predominant in 2008, although the number of observations for each month is highly variable. These observations confirm the seasonal and inter-annual fluctuations of the coastal circulation, rather than poleward flow predominance in summer, at least at the mooring site. Hence, the presence of a seasonal cyclonic cell on 
the shelf of the eastern GoC is not supported by our dataset. Nevertheless, as noted by Criado-Aldeanueva et al. (2009), longer time-series are required to establish a definitive conclusion. Concurrent observations along the inner shelf are also desirable to establish the spatial variations of the coastal circulation. For example, observations off the Oregon coast have indicated that poleward flow patterns are significantly affected by shelf width variations (Kosro, 2005).

\subsection{Inversions in response to wind stress alone}

Water circulation is driven by wind in the $\mathrm{GoC}$, and it is expected that wind has a major effect on the patterns of CCCs. This is well-illustrated with the broad correspondence observed between poleward flow and wind (Figure 9). It is also interesting to note that the correspondence among the alongshore wind time series is reasonably consistent as shown in Figure 10 and plate 1 from supplementary material. Westward winter storms clearly affect the intensity and duration of CCCs (e.g., November 2010 and November 2013 in Figure 3; Figure 4). However, despite some episodic good correspondences between poleward flow and wind (e.g., Figure 10a, b), numerous mismatch periods can be found (Figures 9 and 10c, d; see also the examples provided as supplementary material). In addition, the general patterns of CCCs do not support that they result directly from wind stress action alone. For example, the percentage of time with CCCs is similar in summer and winter (about $40 \%$ ), while poleward winds are comparatively largely predominant in winter (compare Figures $2 \mathrm{~b}$ and $2 \mathrm{c}$ ). Likewise, maximum CCC velocities are as high in summer as in winter despite of lower wind conditions. In particular, the largest poleward flow velocity was associated with mild alongshore wind stress $\left(<0.03 \mathrm{~N} \mathrm{~m}^{-2}\right.$; see August 2010 in Figure 3; see also July 2008 for a similar example of weak wind associated with large CCC velocity). Likewise, the strongest poleward wind events of the time series do not correspond to particularly large CCC velocities (e.g., see the storms occurring in November 2008, at the end of Deployment 2, in Figure 3). Wind action alone also fails to explain why inversions frequently start near the bed rather than near the surface (as exemplified with an arrow in Figure 8a). Furthermore, lags between CCC and westward wind indicate that alongshore flows reverse more easily from equatorward to poleward than the opposite, in concordance with a relaxation process: the development of equatorward flows requires upwellingfavourable wind to blow for some time, while CCCs only require weak winds. This lag was also noted in the SST signal along the Californian coast, where warm water arrives at the beginning of wind relaxation periods but remains for some time after the upwelling wind resumed (Largier et al., 1993; Mace and Morgan, 2006; Melton et al., 2009; Send et al., 1987; Wing et al., 1995).

To examine intermittent linkages between alongshore wind stress and currents at various time scales and periods, the time-series were expanded in time-frequency space with a Cross Wavelet Transform (XWT) analysis (Grinsted et al., 2004). A Paul mother wavelet was used because it is expected to provide a better temporal resolution and thus to identify 
533 isolated events (such as sporadic inversions in the alongshore current direction) more

534 accurately than other wavelets (De Moortel et al., 2004). The cross-wavelet power spectrum

535 was calculated from the XWT results in order to estimate the covariance between each pair

536 of time series as a function of frequency (Figure 13). The statistical significant level (95\%)

537 was estimated using Monte Carlo methods. The colour contours denote cross wavelet

538 power (i.e., the covariance of the two time series) and the arrows designate their phase

539 relationship (in-phase pointing right and out of phase pointing left). The thin black line

540 delimits the cone of influence in which edge effects become significant (Grinsted et al.,

541 2004). The highest wavelet power between alongshore wind stress and currents (both

542 poleward and equatorward) is found in the band period 8-32 days, suggesting that the

543 circulation at the mooring site is mainly forced by large-scale rather than local wind

544 conditions. In agreement, previous studies at the GoC have suggested a strong control of

545 large-scale atmospheric pressure systems on the seasonal inner-shelf (Sánchez et al., 2006)

546 and offshore (Machín et al., 2006) circulations. Of particular interest for the present study,

547 Sánchez et al. (2006) have indicated that alongshore currents near the mooring site are

548 better correlated with wind at the West coast than with the local one. This pattern was also

549 observed in other shelves where the local wind is relatively weak such as the SBC (Hickey et

550 al., 2003). It should be noted, however, that in other upwelling regions (California, Peru,

551 Oregon) the 8-32 days band period also corresponds to coastal trapped waves (CTW)

552 produced by drastic changes in the large scale wind conditions (e.g., Battisti and Hickey,

553 1984; Camayo and Campos, 2006). In detail, our results indicate that CCCs with high

554 common power was mostly associated with an in-phase relationship (arrows pointing to the

555 right), although sometimes wind was leading currents (arrows pointing down; see the

556 examples outlined with green boxes in Figure 13). For large CCC velocities, the cross-wavelet

557 power often extends to shorter periods forming peaks (see the examples outlined with

558 white boxes in Figure 13), suggesting that CCCs are more reactive than equatorward flows

559 to local (i.e., short period) alongshore wind. Note however that the corresponding phase

560 relationship was highly inconstant (e.g., see the variable arrows' direction in the white boxes

561 of Figure 13). As a summary, the coastal water circulation seems to be largely controlled by

562 wind that operates at a (8-32 days) band period which is characteristic of wind-induced

563 current fluctuations in the Iberian upwelling system. The relationship between the short

564 period alongshore wind stress and CCCs was not always clear, indicating that even though

565 local alongshore wind is capable of affecting CCC patterns, it is not their main driving

566 mechanism.

$567 \quad$ 5.4. Relaxation events

568 The observations provided in the previous section show that the action of wind alone 569 generally fails to account for the development of CCCs, whatever a local or basin-scale wind 570 source is considered. In some cases (see $22^{\text {nd }}$ of May 2014 in Plate 1), inversions occurred in 571 a context of decreasing (equatorward) alongshore wind intensity, in concordance with a 572 relaxation process. However, this correspondence was not always observed. As striking 
573 examples, inversions occurred while equatorward wind was intensifying at all sources on 574 the $30^{\text {th }}$ of October 2010 and $12^{\text {th }}$ of July 2014 (Plate 1). It seems therefore that, relaxation 575 or not, alongshore local (or basin-scale) wind poorly controls the development of CCCs.

576 The coherency and cross-correlation (at lag 0) of the alongshore flow and wind rotated in 18 577 sectors of $10^{\circ}$ was then computed to identify which wind direction is best correlated with 578 the alongshore circulation (Figure 14). Both the largest coherency (at the 2-5 days period 579 band) and the largest cross-correlation correspond to wind oriented SE-NW. Similar results 580 were obtained when a lag was introduced in the cross-correlation (with the best correlation 581 for a $16 \mathrm{~h} \mathrm{lag).} \mathrm{Wind} \mathrm{blows} \mathrm{predominantly} \mathrm{south-eastward} \mathrm{but} \mathrm{rarely} \mathrm{north-westward} \mathrm{in} \mathrm{the}$ 582 region, particularly in summer (Figure 2). Hence, the coherency and cross-correlation results 583 indicate that the alongshore circulation is mainly forced by south-eastward wind in the GoC. 584 South-eastward wind proceeds from the rotation around CSV of upwelling-favourable 585 southward wind at the West coast, which ultimately controls the inner-shelf circulation in 586 the GoC (Sánchez et al., 2006). This view is consistent with the XWT results indicating that 587 the coastal circulation at the studied site is mainly controlled by wind operating at the scale 588 of the upwelling system (such as southward wind at the West coast and south-eastward 589 wind at the South coast). Such correspondence between CCCs and upwelling-favourable 590 wind (at the scale of the system) points out towards a relaxation process.

591 In the frame of the CODE experiment, Huyer and Kosro (1987) performed a linear regression 592 analysis between alongshore wind and flow to examine the current direction tendency in 593 the absence of wind (zero intercept of the regression), as an indication of the flow response 594 to relaxation. This approach was applied to the present dataset considering alongshore 595 current and the best correlated SE-NW rotated wind (see Figure 14b). Considering a $16 \mathrm{~h}$ 596 lag, the results indicate that under no wind conditions the flow tends to be poleward $(\sim 1 \mathrm{~cm}$ $\left.597 \mathrm{~s}^{-1}\right)$ in summer and equatorward $\left(\sim 3 \mathrm{~cm} \mathrm{~s}^{-1}\right)$ in winter. Similar tendencies are obtained with a 5980 lag and when storms (wind speed $>5 \mathrm{~m} \mathrm{~s}^{-1}$ ) are discarded. Such flow behaviour is contrary 599 to the shelf circulation scheme (cyclonic in summer, anticyclonic in winter) proposed in 600 previous studies (Criado-Aldeanueva et al., 2009; García-Lafuente et al., 2006; see Section 601 5.2). In summer, this behaviour is concordant with the development of CCCs in response to 602 the unbalance of an APG during the relaxation of upwelling-favourable wind (while in 603 winter, the APG might not be predominant compared to other processes).

604 The points discussed above strongly suggest that the observed linkage between CCCs and 605 (system-scale) upwelling favourable winds in the eastern GoC result from a relaxation 606 process. It is not the objective of the present report to address the dynamics of such 607 process. Nevertheless, it is verified whether realistic relaxation events that match CCC 608 periods can be defined considering northwest-southeast wind at Cadiz buoy. Following 609 Melton et al. (2009), thresholds based on wind intensity and duration were considered to 610 define wind relaxation events. The relaxation begins at a time Tb when (south-eastward) 611 wind velocity drops below a threshold value of $3 \mathrm{~m} \mathrm{~s}^{-1}$ (see the example in Figure 15). 
612 Additionally, it is required that wind blows above this threshold during at least $70 \%$ of the 2

613 days preceding $\mathrm{Tb}$, and below the threshold during more than $50 \%$ of the 2 days following

614 Tb. Successive Tb were separated by at least 1.5 days to be retained. The end of relaxation

615 (Te) is defined when wind is above a threshold of $4 \mathrm{~m} \mathrm{~s}^{-1}$ for at least 36 hours. Note that 616 with a threshold of $3 \mathrm{~m} \mathrm{~s}^{-1}$, as defined for Tb, CCCs would reverse largely after Te. Distinct

617 threshold velocities for $\mathrm{Tb}$ and Te are consistent with our observations (although for 618 alongshore wind) that poleward flows are more difficult to reverse than equatorward flows.

619 A 5-day relaxation period defined with the above criteria is presented in Figure 15. In this 620 example, the development of a poleward flow corresponds closely to the relaxation 621 window, and its intensity is somewhat modulated by the wind speed.

622 Overall, the defined periods of wind relaxation occur all year-round and match well (91\%)

623 the periods of poleward flow (Figure 9). Few of these periods are not associated with 624 relaxation, such as when CCCs are weak $\left(<0.1 \mathrm{~m} \mathrm{~s}^{-1}\right)$ or when relaxations could not be 625 defined at the start and end of deployments. Only one strong CCC event ( $9^{\text {th }}$ of November 626 2008) corresponded to a winter storm that was not recognised as a relaxation event by the 627 procedure. The selected criteria for the definition of relaxation events are similar to those 628 proposed at the SBC (see Melton et al., 2009). The main difference is that the wind speed 629 thresholds are lower in our case, in particular at the start of relaxation ( $3 \mathrm{~m} \mathrm{~s}^{-1}$ in the GoC, 630 against $5 \mathrm{~m} \mathrm{~s}^{-1}$ in the SBC). However, the thresholds along the California coast were defined 631 based on wind at the west coast, where wind conditions are stronger than at the south 632 coast. Finally, the proposed relaxation criteria for the GoC are plausible and give reasonable 633 results; they are however subjective and should be based on objective identification 634 procedures to be definitive.

\section{6. Conclusions}

636 This study has characterised, for the first time, the main patterns of CCCs based on a 637 multiyear time series of current observations on the inner shelf of the GoC. The coastal 638 circulation is mainly alongshore and barotropic. Poleward flows, up to $0.4 \mathrm{~m} \mathrm{~s}^{-1}$, develop all 639 year-round but are not associated with warmer water in winter. During the upwelling 640 season, CCCs control the occurrence of warm water, increasing the vertical stratification, 641 with faster flows leading to larger temperature increases. The mean duration of CCC events 642 was 3 days, even though long events lasting up to 15 days were observed. Peak velocity and 643 duration are well-correlated for CCC events less than 5 days-long. Inversions often start near 644 the bed and are accompanied with the development of a 2-layer cross-shore flow often 645 typical of downwelling conditions. Such cross-shore water exchanges during poleward flows 646 may affect the availability of nutrients at near-shore areas should be addressed in future 647 studies.

648 In total, about 1 inversion per week was observed, corresponding to the occurrence of CCCs 649 during as much as $40 \%$ of the time, with no seasonal trend. Thus, the dynamics of the 
studied coastal area is dominated by the temporary development of CCCs all year-round.

651 Although longer, the periods of the annual cycle governed by the Ekman mechanism, 652 inducing the upwelling of cold water along the coast and the associated eastward 653 geostrophic flow, are comparable to those governed by the CCCs. Regarding this fact, it is 654 excessive to assume the region as an upwelling system, defined as a system where 655 upwelling prevails during at least a substantial part of the year (in some places 656 permanently). Contrarily to the African boundary of the CCUS, the coupling between 657 atmospheric forcing, ocean circulation, biogeochemical cycling and food web dynamics 658 attributed to the Ekman dynamics may not fully develop in the northern margin of the GoC. 659 The latter is rather a system where upwelling events do occur during the western Iberian 660 upwelling season.

661 At the local or basin scales, poleward winds clearly affect the pattern (duration, velocity) of 662 CCCs, particularly during winter storms. However, the general patterns of CCCs do not 663 reproduce the seasonal patterns of alongshore wind stress. This shows that CCCs are not 664 produced as a result of the sole action of wind stress, as demonstrated by the mismatch 665 between alongshore flow and wind, even when various wind sources are considered. In 666 contrast, wavelet analysis indicates that CCCs are best correlated with large-scale wind 667 occurring in a band period characteristic of the upwelling system. Concordantly, alongshore 668 currents exhibit largest coherency and cross-correlation with south-eastward wind which 669 proceeds from the counter clockwise rotation around CSV of upwelling favourable 670 southward wind at the West coast. The inner-shelf circulation at the GoC seems therefore to 671 be largely controlled by large-scale wind conditions, as proposed in previous studies 672 (Sánchez et al., 2006). Overall, our results support that the unbalance of an APG due to the 673 relaxation of large-scale upwelling-favourable wind drives the development of CCCs in the 674 eastern GoC. Considering south-eastward wind, realistic thresholds can be defined for the 675 identification of relaxation periods that include most of the observed periods with poleward 676 flow. Future work should aim at identifying the main process that produce the APG, and at 677 assessing the contribution of CTW.

\section{Acknowledgments}

679 The authors are grateful to (1) "Puertos del Estado" (Spain) for making available the wind 680 data from the Cadiz buoy and HIRLAM model, (2) Portuguese Hydrographic Institute (IH) for 681 the wind data from Tavira Station, and (3) A. Peliz for providing the ASCAT wind data. 682 Thanks are extended to Tunipex and Marcos Rosa for assistance in the field work, and to Rui 683 Taborda, André Aires Cid, Pedro Pousão and Paulo Oliveira for their contributions to the 684 ADCP earlier deployments. Erwan Garel benefited from a grant from the SHORE project 685 (Shoreface morphodynamics: an integrated approach - PTDC/MAR-EST/3485/2012) funded 686 by the Portuguese Foundation of Sciences and Technology (FCT) and Irene Laiz was partly 687 supported by the Spanish Ministry of Science and Technology through the "Juan de la Cierva 688 Programme". This is a contribution of the SHORE and SEAFARE (Sustainable management 
689

690

691

692

693

694

695

696

697

698

699

700

701

702

703

704

705

706

707

708

709

710

711

712

713

714

715

716

717

718

719

720

721

722 and protection of the resources of marine spaces - Interreg Atlantic Area Programme 1/1/2010- 31/12/2012) projects.

\section{References}

Battisti, D.S., and Hickey, B.M., 1984, Application of remote wind forced coastal trapped wave theory to the Oregon and Washington coasts: Journal of Physical Oceanography, v. 14, p. 887-903.

Camayo, R., and Campos, E.J.D., 2006, Application of wavelet transform in the study of coastal trapped waves off the west coast of South America: Geophysical Research Letters, v. 33, p. L22601.

Criado-Aldeanueva, F., García-Lafuente, J., Navarro, G., and Ruiz, J., 2009, Seasonal and interannual variability of the surface circulation in the eastern Gulf of Cadiz (SW Iberia): Journal of Geophysical Research, v. 114.

Criado-Aldeanueva, F., García-Lafuente, J., Vargas, J.M., Del Río, J., Sánchez, A., Delgado, J., and Sánchez, J.C., 2006, Wind induced variability of hydrographic features and water masses distribution in the Gulf of Cadiz (SW Iberia) from in situ data: Journal of Marine Systems, v. 63, p. 130-140.

De Moortel, I., Munday, S.A., and Hood, A.W., 2004, Wavelet analysis: The effect of varying basic wavelet parameters: Solar Physics, v. 222, p. 203-228.

Dever, E.P., 2004, Objective maps of near-surface flow states near Point Conception, California: Journal of Physical Oceanography, v. 34, p. 444-461.

Dudas, S.E., Grantham, B.A., Krinincich, A.R., Menge, B.A., Lubchenco, J., and Barth, J.A., 2008, Current reversals as determinants of intertidal recruitment on the central Oregon coast: ICES Journal of Marine Science, v. 66, p. 396-407.

Fawcett, A.L., Pitcher, G.C., and Shillington, F.A., 2008, Nearshore currents on the southern Namaqua shelf of the Benguela upwelling system: Continental Shelf Research, v. 28, p. 1026-1039.

Fiúza, A.F.G., 1983, Upwelling Patterns off Portugal: New York, Plenum.

Fiúza, A.F.G., Macedo, M.E., and Guerreiro, M.R., 1982, Climatological space and time variation of the Portuguese coastal upwelling: Oceanologica Acta, v. 5, p. 31- 40.

Folkard, A.W., Davis, P.A., Fiúza, A.F.G., and Ambar, I., 1997, Remotely sensed se surface thermal patterns in the Gulf of Cádiz and the Strait of Gibraltar: variability, correlations, and relationships with the surface wind field: Journal of Geophysical Research, v. 102, p. 5669-5683. 
Gan, J., and Allen, J.S., 2002, A modeling study of shelf circulation off northern California in the region of the Coastal Ocean Dynamics Experiment: Response to relaxation of upwelling winds: Journal of Geophysical Research: Oceans, v. 107, p. 3123.

García-Lafuente, J., Delgado, J., Criado-Aldeanueva, F., Bruno, M., del Río, J., and Miguel Vargas, J., 2006, Water mass circulation on the continental shelf of the Gulf of Cádiz: Deep Sea Research Part II: Topical Studies in Oceanography, v. 53, p. 1182-1197.

Garel, E., and Ferreira, Ó., 2013, Fortnightly Changes in Water Transport Direction Across the Mouth of a Narrow Estuary: Estuaries and coasts, v. 36, p. 286-299.

Grinsted, A., Moore, J.C., and Jevrejeva, S., 2004, Application of the cross wavelet transform and wavelet coherence to geophysical time series: Nonlinear Processes in Geophysics, v. 11, p. 561-566.

Harms, S., and Winant, C.D., 1998, Characteristic patterns of the circulation in the Santa Barbara Channel: Journal of Geophysical Research: Oceans, v. 103, p. 3041-3065.

Haynes, R., Barton, E.D., and Pilling, I., 1993, Development, persistence, and variability of upwelling filaments off the Atlantic coast of the Iberian Peninsula: Journal of Geophysical Research, v. 98, p. 22,681-22,692.

Hickey, B.M., Dobbins, E.L., and Allen, S.E., 2003, Local and remote forcing of currents and temperature in the central Southern California Bight: Journal of Geophysical Research: Oceans, v. 108, p. n/a-n/a.

Huyer, A., and Kosro, P., 1987, Mesoscale surveys over the shelf and slope in the upwelling region near Point Arena, California: Journal of Geophysical Research, v. 92, p. 16551681.

Kosro, P.M., 2005, On the spatial structure of coastal circulation off Newport, Oregon, during spring and summer 2001 in a region of varying shelf width: Journal of Geophysical Research: Oceans, v. 110, p. n/a-n/a.

Large, W.G., and Pond, S., 1981, Open ocean momentum flux measurements in moderate to strong winds: Journal of physical oceanography, v. 11, p. 324-336.

Largier, J.L., Magnell, B.A., and Winant, C.D., 1993, Subtidal circulation over the northern California shelf: Journal of Geophysical Research, v. 98, p. 18,147-18,179.

Lentz, S.J., and Chapman, D.C., 1989, Seasonal differences in the current and temperature variability over the northern California shelf during the Coastal Ocean Dynamics Experiment: Journal of Geophysical Research, v. 94.

Lobo, F.J., Sánchez, R., González, R., Dias, J.M.A., Hernández-Molina, F.J., Fernández-Salas, L.M., Díaz del Río, V., and Mendes, I., 2004, Contrasting styles of the Holocene highstand sedimentation and sediment dispersal systems in the northern shelf of the Gulf of Cadiz: Continental Shelf Research, v. 24, p. 461-482. 
Mace, A.J., and Morgan, S.G., 2006, Biological and physical coupling in the lee of a small headland: Contrasting transport mechanisms for crab larvae in an upwelling region: Marine Ecology Progress Series, v. 324, p. 185-196.

Machín, F., Pelegrí, J.L., Marrero-Díaz, A., Laiz, I., and Ratsimandresy, A.W., 2006, Nearsurface circulation in the southern Gulf of Cádiz: Deep Sea Research Part II: Topical Studies in Oceanography, v. 53, p. 1161-1181.

Mauritzen, C., Morel, Y., and Paillet, J., 2001, On the influence of Mediterranean water on the central waters of the North Atlantic Ocean: Deep-Sea Research I, v. 48, p. 347381.

Melton, C., Washburn, L., and Gotschalk, C., 2009, Wind relaxations and poleward flow events in a coastal upwelling system on the central California coast: Journal of Geophysical Research - Oceans, v. 114.

Mittelstaedt, E., 1991, The ocean boundary along the Northwest African coast: Circulation and oceanographic properties at the sea surface: Progress in Oceanography, v. 26, p. 307-355.

Navarro, G., and Ruiz, J., 2006, Spatial and temporal variability of phytoplankton in the Gulf of Cádiz through remote sensing images: Deep Sea Research II, v. 53, p. 1241-1260.

Pelegrí, J.L., Arístegui, J., Cana, L., González-Dávila, M., Hernández-Guerra, A., HernándezLeón, S., Marrero-Díaz, A., Montero, M.F., Sangrà, P., and Santana-Casiano, M., 2005a, Coupling between the open ocean and the coastal upwelling region off Northwest Africa: Water recirculation and offshore pumping of organic matter: Journal of Marine Systems, v. 54, p. 3-37.

Pelegrí, J.L., Marreo-Díaz, A., Ratsimandresy, A.W., Antoranz, A., Cisneros-Aguirre, J., Gordo, C., Grisolía, D., Hernández-Guerra, A., Laiz, I., Martínez, A., G.Parrilla, PérezRodríguez, P., Rodríguez-Santana, A., and Sangrà, P., 2005b, Hydrographic cruises off Northwest Africa: The Canary Current and the Cape Ghir region: Journal of Marine Systems, v. 54, p. 39-63.

Peliz, Á., Santos, A.M.P., Oliveira, P.B., and Dubert, J., 2004, Extreme cross-shelf transport induced by eddy interactions southwest of Iberia in winter 2001: Geophysical Research Letters, v. 31, p. 1-4.

Peliz, A.J., and Fiuza, A.F.G., 1999, Temporal and spatial variability of CZCS-derived phytoplankton pigment concentrations off the western Iberian Peninsula: International Journal of Remote Sensing, v. 20, p. 1363-1403.

Relvas, P., and Barton, E.D., 2002, Mesoscale patterns in the Cape Sa o Vicente (Iberian Peninsula) upwelling region: Journal of Geophysical Research, v. 107.

Sánchez, R.F., Mason, E., Relvas, P., da Silva, A.J., and Peliz, Á., 2006, On the inner-shelf circulation in the northern Gulf of Cádiz, southern Portuguese shelf: Deep Sea Research Part II: Topical Studies in Oceanography, v. 53, p. 1198-1218. 
Sánchez, R.F., and Relvas, P., 2003, Spring-summer climatological circulation in the upper layer in the region of Cape St. Vincent, Southwest Portugal: ICES Journal of Marine Science, v. 60, p. 1232-1250.

Send, U., Beardsley, R.C., and Winant, C.D., 1987, Relaxation from upwelling in the Coastal Ocean Dynamics Experiment: Journal of Geophysical Research: Oceans, v. 92, p. 1683-1698.

Stacey, M.T., Burau, J.R., and Monismith, S.G., 2001, Creation of residual flows in a partially stratified estuary: Journal of Geophysical Research, v. 106, p. 17013-17043.

Teles-Machado, A., Peliz, Á., Dubert, J., and Sánchez, R.F., 2007, On the onset of the Gulf of Cadiz Coastal Countercurrent: Geophysical Research Letters, v. 34, p. L12601.

Vargas, J.M., García-Lafuente, J., Delgado, J., and Criado, F., 2003, Seasonal and windinduced variability of Sea Surface Temperature patterns in the Gulf of Cádiz: Journal of Marine Systems, v. 38, p. 205-219.

Washburn, L., Fewings, M.R., Melton, C., and Gotschalk, C., 2011, The propagating response of coastal circulation due to wind relaxations along the central California coast: Journal of Geophysical Research: Oceans, v. 116, p. C12028.

Washburn, L., and McPhee-Shaw, E., 2013, Coastal transport processes affecting inner-shelf ecosystems in the California Current System: Oceanography, v. 26, p. 34-43.

Wilson, J.R., Broitman, B.R., Caselle, J.E., and Wendt, D.E., 2008, Recruitment of coastal fishes and oceanographic variability in central California: Estuarine, Coastal and Shelf Science, v. 79, p. $483-490$.

Winant, C., Alden, D., Dever, E., Edwards, K., and Hendershott, M., 1999, Near-surface trajectories off central and southern California: Journal of Geophysical Research, v. 104 , p. $15,713-15,726$.

Winant, C.D., Beardsley, R.C., and Davis, R.E., 1987, Moored wind, temperature, and current observations made during the Coastal Ocean Dynamics Experiments 1 and 2 over the northern California continental shelf and upper slope: Journal of Geophysical Research, v. 92, p. 1569- 1604.

Winant, C.D., Dever, E.P., and Hendershott, M.C., 2003, Characteristic patterns of shelf circulation at the boundary between central and southern California: Journal of Geophysical Research, v. 108, p. 3021.

Wing, S.R., Botsford, L.W., Largier, J.L., and Morgan, L.E., 1995, Spatial structure of relaxation events and crab settlement in the northern California upwelling system: Marine Ecology Progress Series, v. 128, p. 199-211.

Woodson, C.B., Washburn, L., Barth, J.A., Hoover, D.J., Kirincich, A.R., McManus, M.A., Ryan, J.P., and Tyburczy, J., 2009, Northern Monterey Bay upwelling shadow front: 
Observations of a coastally and surface trapped buoyant plume: Journal of Geophysical Research, v. 114, p. C12013.

Wooster, W.S., Bakun, A., and McLain, D.R., 1976, The seasonal upwelling cycle along the eastern boundary of the North Atlantic: Journal of Marine Research, v. 34, p. 131141.

\section{Table captions}

Table 1. ADCP deployment periods.

Table 2. Duration of ADCP observations (in hours, hr) and patterns of coastal countercurrents (CCCs) for each month and for all the dataset: CCC occurrence (percentage of time with poleward flow); monthly mean (and total, in brackets) number of current inversions; monthly mean (and maximum, in brackets) duration of CCC events (in days). No data were recorded in March.

Table 3. Percentage of occurrence of poleward flows in July, August, November and December, per year. The number of hourly observations for each month is indicated in brackets (“-": no observation).

\section{Figure captions}

Figure 1. Localisation of the ADCP mooring (red point) and wind sources used in this study (green stars). ETOPO1 bathymetric contours $(-100 \mathrm{~m},-500 \mathrm{~m}$ and $-1000 \mathrm{~m})$ are indicated. CSV: Cape St Vicente; CSM: Cape Santa Maria.

Figure 2. Wind roses of the concatenated observations represented with the oceanographic convention: (a) all data; (b) June-August; and (c) November-January.

Figure 3. (a) Depth averaged alongshore velocity $\left(u_{x}\right.$, red line, positive equatorward, $\mathrm{m} \mathrm{s}^{-1}$ ); (b) depth averaged cross-shore velocity ( $u_{y}$, green line, positive landward, $\mathrm{m} \mathrm{s}^{-1}$ ); (c) nearbed temperature (black line, ${ }^{\circ} \mathrm{C}$ ); and, (d) alongshore wind stress at Cadiz buoy ( $\mathrm{tw}_{\mathrm{x}}$, blue line, N. $\mathrm{m}^{-2}$ ) during the 7 ADCP deployment periods. The tick interval along the $\mathrm{x}$-axis is 10 days, but note that the dates are not continuous: for visualisation, the 7 continuous timeseries are concatenated chronologically and distinguished with grey and white background colours (see also the labels on top of the graph).

Figure 4. Monthly patterns of CCC events: (a) duration o; (b) peak velocity. The red lines are monthly-averaged.

Figure 5. Maximum peak velocity of CCC events Vs duration. Summer (June-August) and winter (November-January) months are represented with blue and red circles, respectively. 
867 Figure 6. Histogram of temperature data considering the entire time-series (blue), the 868 periods with CCCs (green), and the periods with CCCs during the upwelling season (May869 October; brown).

870 Figure 7. Peak alongshore velocity $\left(\mathrm{u}_{\max }, \mathrm{m} \mathrm{s}^{-1}\right)$ and associated temperature increase $\left(\mathrm{dT},{ }^{\circ} \mathrm{C}\right)$ 871 during CCC events in summer (June-August). The red line indicates the linear fit $(r=0.89)$.

872 Figure 8. Vertical structure of the (a) alongshore flow $\left(\mathrm{m} \mathrm{s}^{-1}\right)$ and (b) cross-shore flow at the 873 mooring site. (c) Temperature measured by the thermistors near the surface $(7 \mathrm{~m}$ depth, 874 blue line), at mid depth (13 $\mathrm{m}$ depth, red line) and near the bed (18 $\mathrm{m}$ depth, black line), and 875 by the bottom-mounted ADCP ( $21 \mathrm{~m}$, green line). The arrows and vertical dashed lines 876 indicate an example of baroclinic alongshore flow at current inversion (see also Figures $11 \mathrm{~g}$ 877 and $12 \mathrm{~h})$.

878 Figure 9. Comparison of periods with CCC (red) and periods with westward alongshore wind 879 from various sources (Hirlam: light blue; ASCAT: grey; Tavira: green; Cadiz buoy: dark blue) 880 and with the relaxation periods (black). Wind-CCC relations are described in Section 4.3., 881 while relaxation events are defined and compared with CCC in Section 5.4. The time series 882 of each deployment are concatenated and separated with vertical lines (see also the labels 883 on top of the graph). The percentage of time with poleward wind during poleward flow 884 faster than $0.1 \mathrm{~m} \mathrm{~s}^{-1}$ is also indicated.

885 Figure 10. Examples where periods of poleward currents (upper row) and wind (lower row, 886 with Tavira: blue; Cadiz: black; ASCAT: red; Hirlam: green) match in October 2008 (a) and 887 November 2012 (b) and where they do not match in May 2008 (c) and January 2014 (d).

888 Figure 11. Energy $\left(\mathrm{m}^{2} \cdot \mathrm{s}^{-2}\right)$ of the near-bed PC1 (a) and PC2 (b) alongshore current 889 components; Normalised velocity of the near-bed PC1 (c) and PC2 (d); Velocity ( $\mathrm{m} \mathrm{s}^{-1}$ ) of the 890 recorded alongshore currents (e). The grey areas indicate the main periods of poleward flow 891 near the bed. The vertical dashed lines indicate the time of the examples of flow structure 892 displayed on the right of the figure: $19^{\text {th }}$ of August 2014 (f) and $7^{\text {th }}$ of September $2014(\mathrm{~g})$. 893 The latter example corresponds to the event annotated with arrows and dashed lines in 894 Figure 8 and to Figure $12 \mathrm{~h}$.

895 Figure 12. Energy $\left(\mathrm{m}^{2} \cdot \mathrm{s}^{-2}\right)$ of the near-bed PC1 (a) and PC2 (b) cross-shore current 896 components; Normalised velocity of the near-bed PC1 (c) and PC2 (d); Velocity ( $\mathrm{m} \mathrm{s}^{-1}$ ) of the 897 recorded depth-average cross-shore (e) and alongshore (f) flow. The grey areas indicate the 898 periods of poleward flow. The vertical dashed lines indicate the time of the examples of flow 899 structure displayed on the right of the figure: $20^{\text {th }}$ of August $2014(\mathrm{~g})$ and $7^{\text {th }}$ of September 9002014 (h). The latter example corresponds to the event annotated with arrows and dashed 901 lines in Figure 8 and to Figure 11g. 
902 Figure 13. Cross wavelet transform analyses between the alongshore wind stress and (depth

903 averaged) currents for each deployment. Arrows indicate the phase relationship between 904 the 2 time-series, with in-phase pointing right and out of phase pointing left. White regions 905 on both ends of the graphs indicate the "cone of influence", where edge effects become 906 important. The negative alongshore current velocities are indicated on top of each graph 907 (white line) to indicate the periods of poleward flow; the horizontal dashed line is $-0.1 \mathrm{~m} \mathrm{~s}^{-1}$. 908 Green boxes exemplifies periods of CCC with high common wavelet power. White boxes 909 exemplify the expansion of the common wavelet power from long to shorter periods during 910 large CCC events. Note that the scale of the $x$ - and $y$-axis varies for each deployment.

911 Figure 14. Magnitude of the squared coherence (a) and maximum cross-correlation at lag 0 912 (b) between the alongshore current and wind (Cadiz buoy) rotated per $10^{\circ}$ sector. The wind 913 direction is the direction the wind is blowing towards.

914 Figure 15. Example of a 5-day wind relaxation period as defined by $\mathrm{Tb}$ and Te described in 915 the text. The alongshore current velocity is indicated in blue ( $\mathrm{m} \mathrm{s}^{-1}$, left $\mathrm{y}$-axis). Wind velocity 916 rotated along the NW-SE direction is in green (right y-axis, $\mathrm{m} \mathrm{s}^{-1}$ ). Supplementary Material

917 Plate 1. Examples of the alongshore current and wind velocities (equatorward: positive; 918 poleward negative) at times of poleward flows. Winds are from various sources: Tavira 919 coastal station (blue); Cadiz offshore buoy (black); ASCAT remotely-sensed data (red); and 920 Hirlam model outputs (green). 


\begin{tabular}{|l|l|l|l|}
\hline Deployment & Start & End & Duration (days) \\
\hline $\mathbf{1}$ & 09-May-2008 & 31-Aug-2008 & 114 \\
\hline $\mathbf{2}$ & 02-Oct-2008 & 05-Dec-2008 & 64 \\
\hline $\mathbf{3}$ & $03-$ Aug-2010 & 14-Dec-2010 & 133 \\
\hline $\mathbf{4}$ & $04-$ Nov-2013 & 08-Feb-2014 & 96 \\
\hline $\mathbf{5}$ & $16-$ Apr-2014 & 18-Jul-2014 & 93 \\
\hline $\mathbf{6}$ & $05-$ Aug-2014 & 02-Oct- 2014 & 58 \\
\hline $\mathbf{7}$ & $18-$ Nov-2014 & 28-Dec-2014 & 40 \\
\hline
\end{tabular}




\begin{tabular}{|c|c|c|c|c|c|c|c|c|c|c|c|c|c|c|}
\hline & Jan. & Feb. & Apr. & May & Jun. & Jul. & Aug. & Sep. & Oct. & Nov. & Dec. & Winter & Summer & All data \\
\hline Observations (hr) & 744 & 190 & 351 & 1,282 & 1,440 & 1,160 & 2,056 & 1,440 & 1,483 & 2,377 & 1,823 & 4944 & 4656 & 14,346 \\
\hline CCC occurrence (\%) & 25 & 9 & 19 & 35 & 45 & 34 & 42 & 57 & 44 & 47 & 44 & 43 & 41 & 42 \\
\hline $\begin{array}{l}\text { Monthly mean (total) } \\
\text { number of inversions }\end{array}$ & $\begin{array}{l}2.9 \\
(3) \\
\end{array}$ & $\begin{array}{l}3.8 \\
(1) \\
\end{array}$ & $\begin{array}{l}4.1 \\
(2) \\
\end{array}$ & $\begin{array}{l}4.5 \\
\text { (8) } \\
\end{array}$ & $\begin{array}{l}4.5 \\
\text { (9) } \\
\end{array}$ & $\begin{array}{l}2.5 \\
\text { (4) } \\
\end{array}$ & $\begin{array}{l}4.5 \\
(13) \\
\end{array}$ & $\begin{array}{l}5.5 \\
(11) \\
\end{array}$ & $\begin{array}{l}5.3 \\
(11) \\
\end{array}$ & $\begin{array}{l}4.2 \\
(14) \\
\end{array}$ & $\begin{array}{l}2.4 \\
(6) \\
\end{array}$ & $\begin{array}{l}3.3 \\
(23) \\
\end{array}$ & $\begin{array}{l}4.0 \\
(26) \\
\end{array}$ & $\begin{array}{l}4.1 \\
(82) \\
\end{array}$ \\
\hline $\begin{array}{l}\text { Monthly mean (max) } \\
\text { duration of inversion } \\
\text { (days) }\end{array}$ & $\begin{array}{l}2.6 \\
(5.4) \\
\end{array}$ & $\begin{array}{l}0.69 \\
(0.69) \\
\end{array}$ & $\begin{array}{l}1.3 \\
(1.4) \\
\end{array}$ & $\begin{array}{l}2.3 \\
(6.1) \\
\end{array}$ & $\begin{array}{l}3 \\
(6.7) \\
\end{array}$ & $\begin{array}{l}3.4 \\
(8.4) \\
\end{array}$ & $\begin{array}{l}3.3 \\
(9.4) \\
\end{array}$ & $\begin{array}{l}2.5 \\
(8.3) \\
\end{array}$ & $\begin{array}{l}2.4 \\
(6) \\
\end{array}$ & $\begin{array}{l}3.6 \\
(14.6) \\
\end{array}$ & $\begin{array}{l}3.7 \\
(8.7) \\
\end{array}$ & $\begin{array}{l}3.4 \\
(14.6) \\
\end{array}$ & $\begin{array}{l}3.2 \\
(9.4) \\
\end{array}$ & $\begin{array}{l}2.9 \\
(14.6) \\
\end{array}$ \\
\hline
\end{tabular}




\begin{tabular}{|l|l|l|l|l|}
\hline Year & July & August & November & December \\
\hline 2008 & $32 \%(744)$ & $37 \%(730)$ & $28 \%(720)$ & $30 \%(101)$ \\
\hline 2010 & - & $59 \%(687)$ & $42 \%(720)$ & $82 \%(322)$ \\
\hline 2013 & - & - & $55 \%(637)$ & $53 \%(744)$ \\
\hline 2014 & $37 \%(416)$ & $29 \%(639)$ & $89 \%(300)$ & $17 \%(656)$ \\
\hline
\end{tabular}




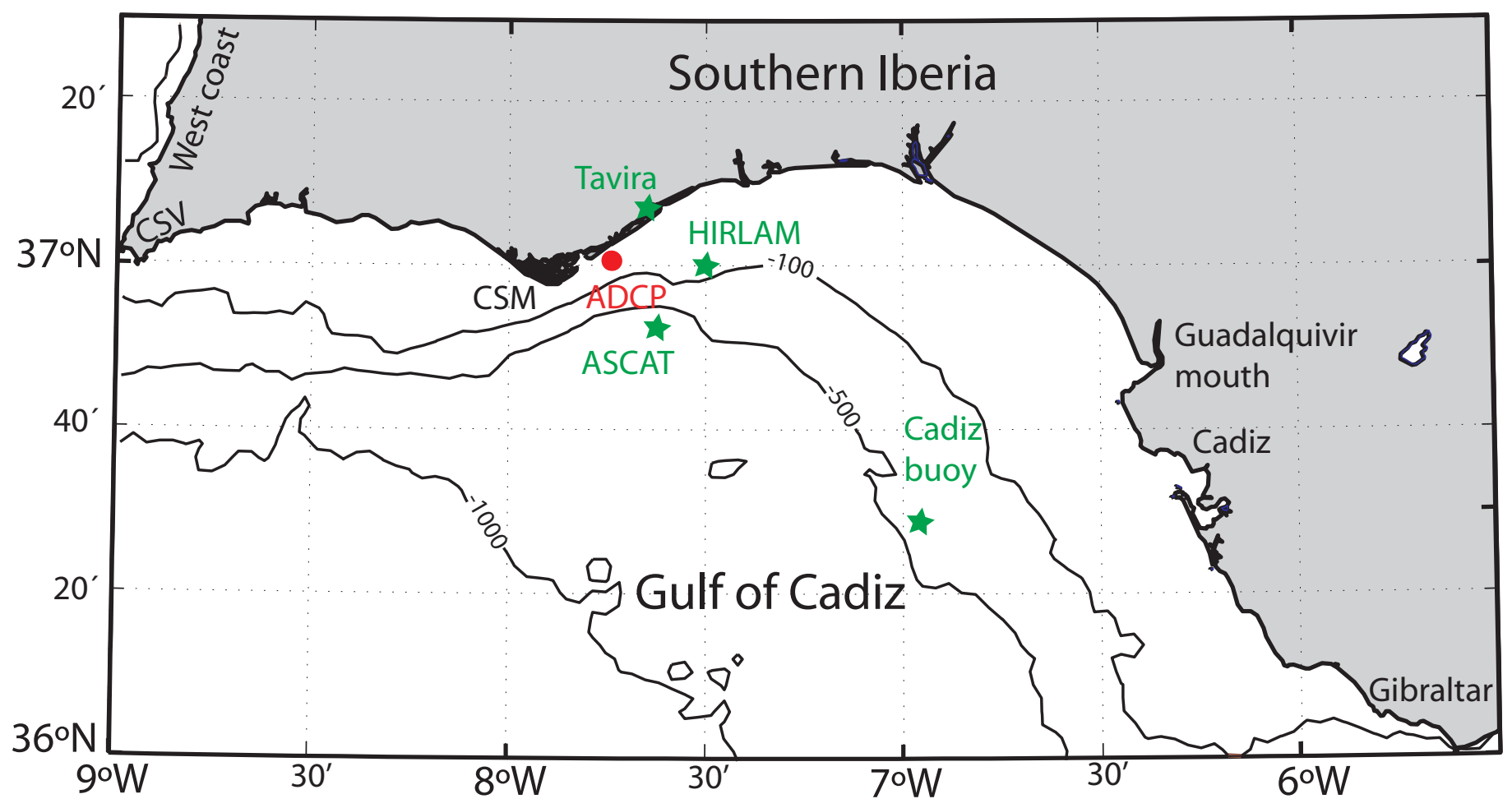


(a)

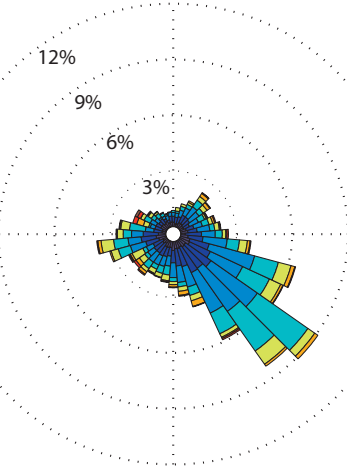

(b)

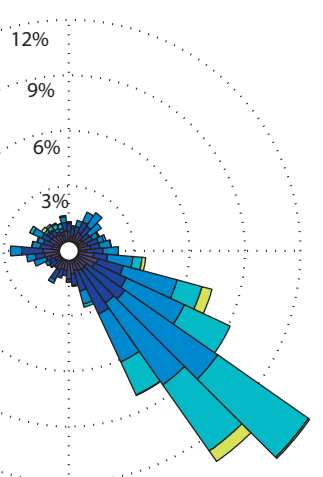

(c)

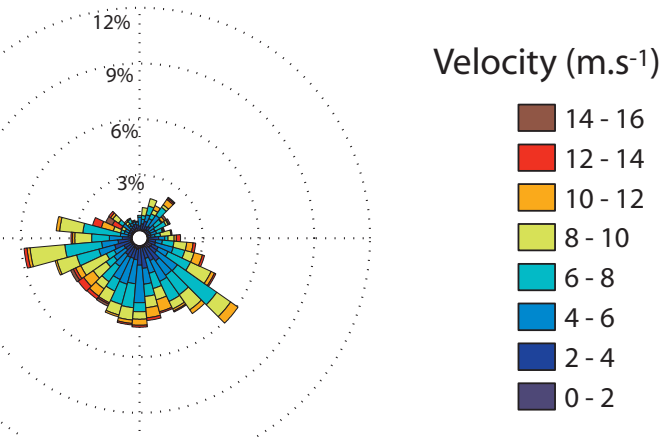


(a)
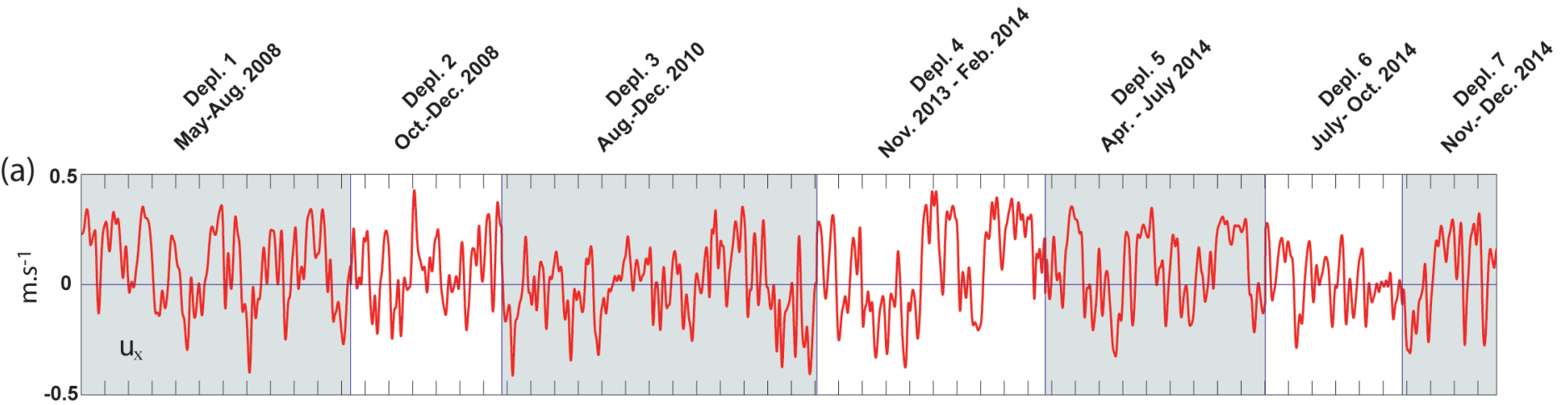

(b) 0.1

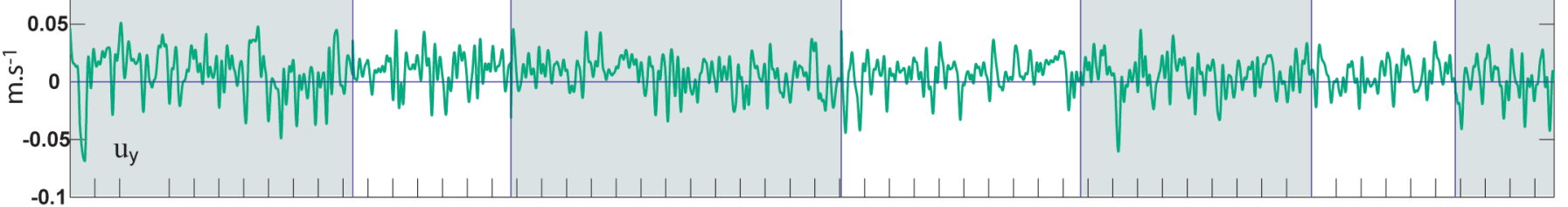

(c) 25 Temperature

${ }_{15}^{20}$

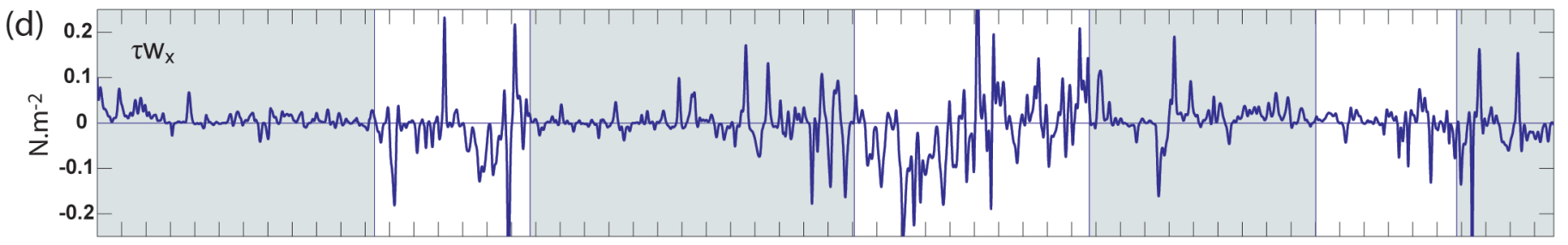

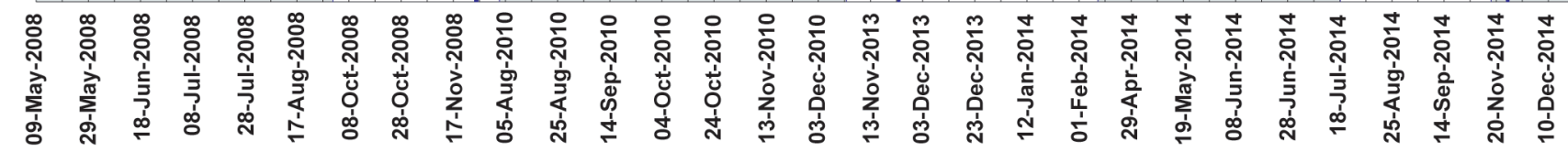


(a)

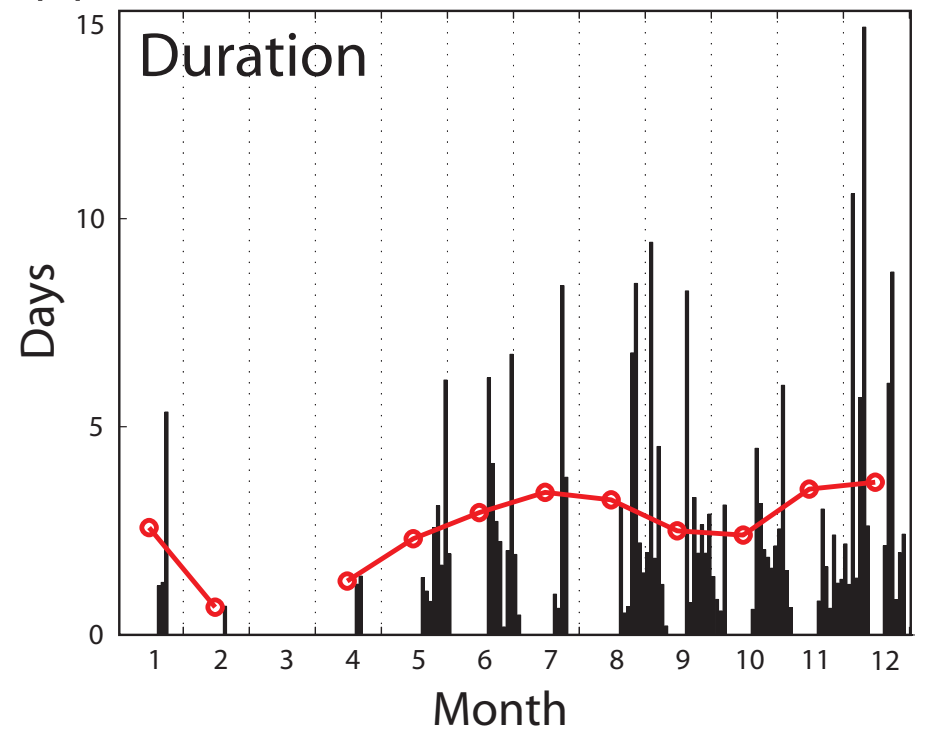

(b)

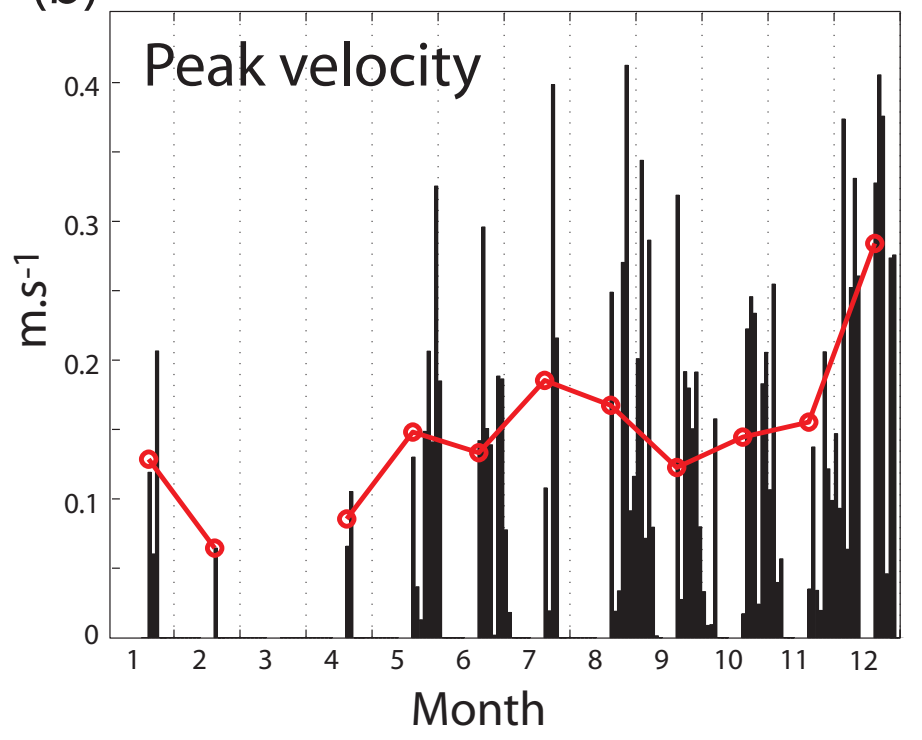




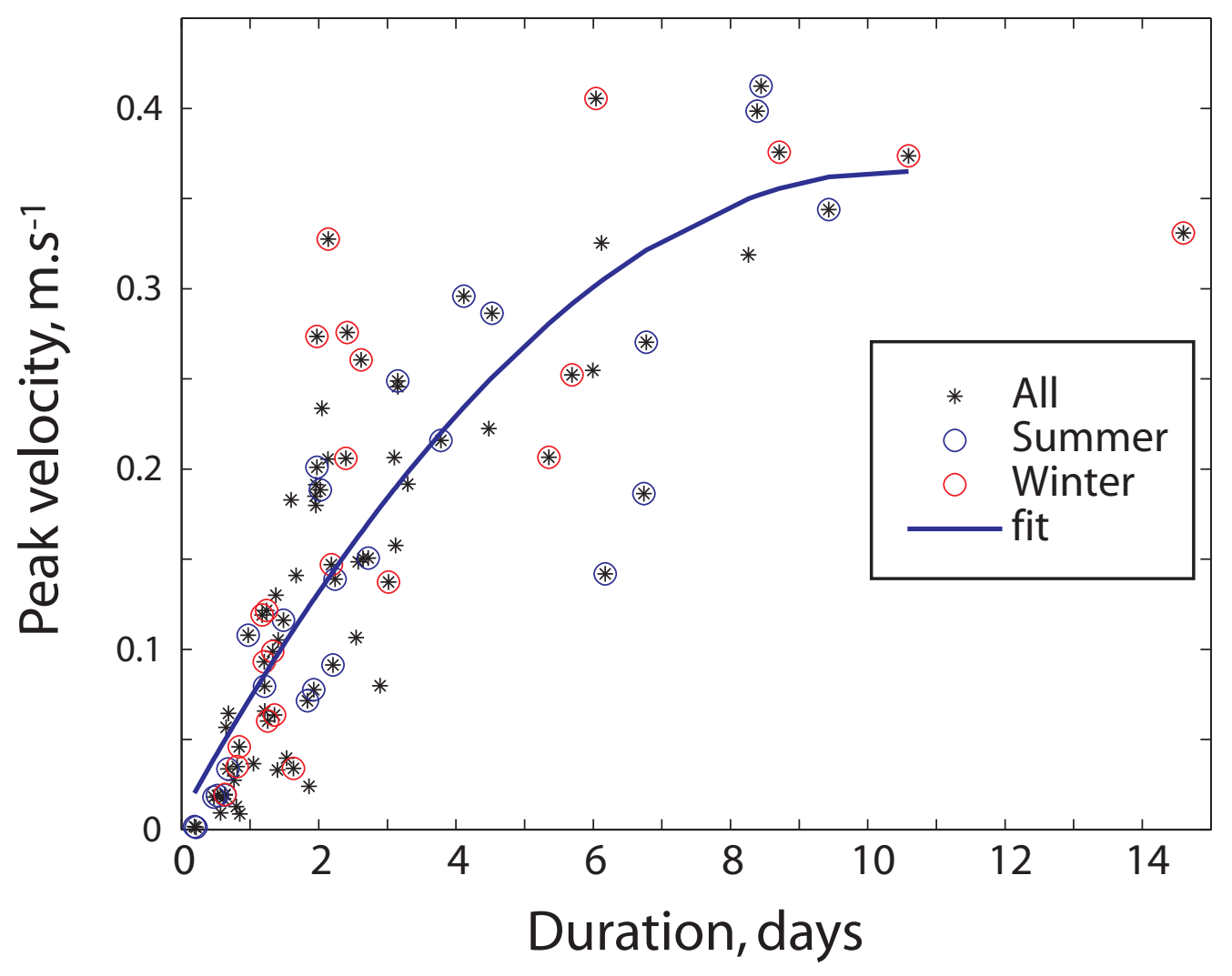




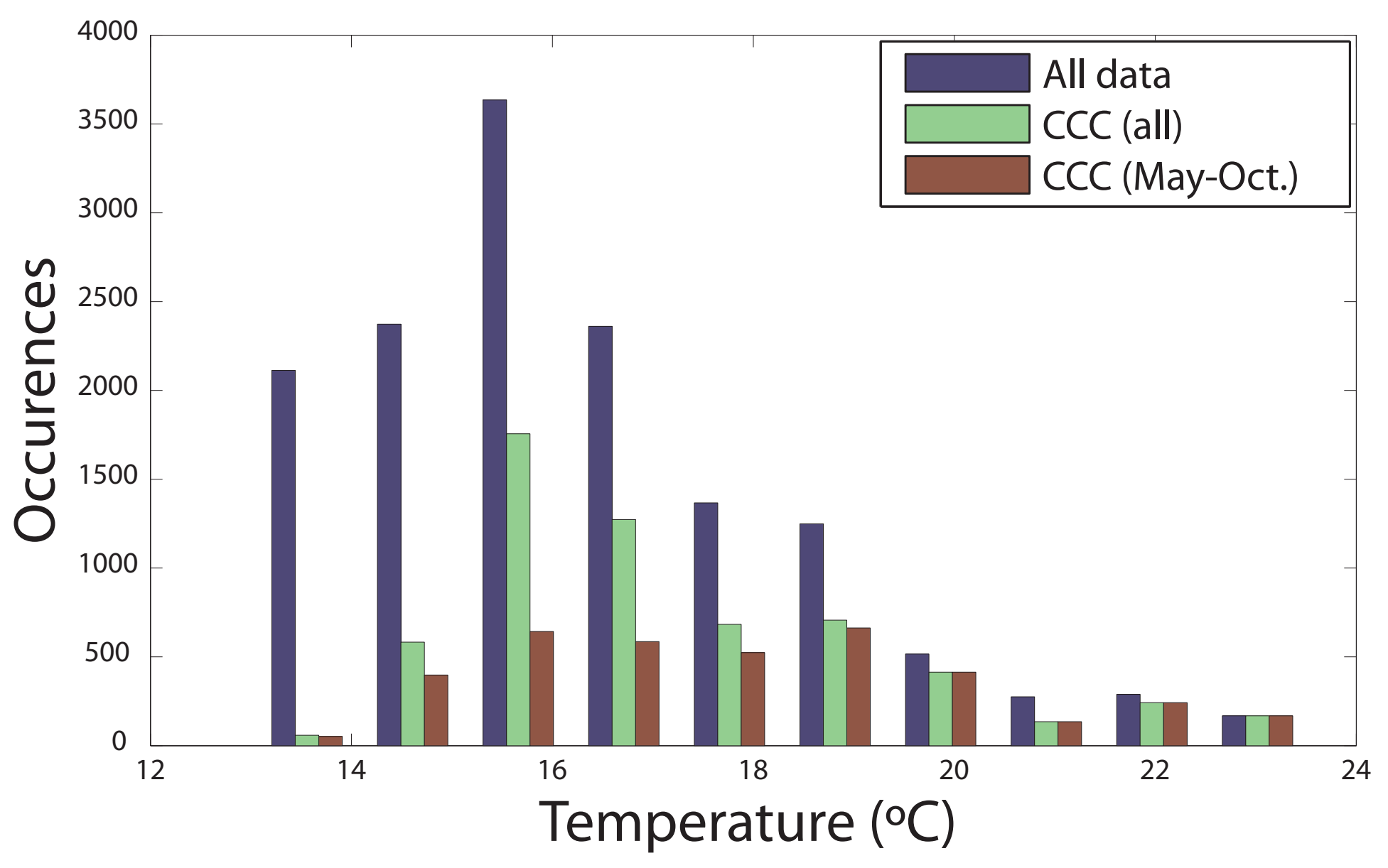




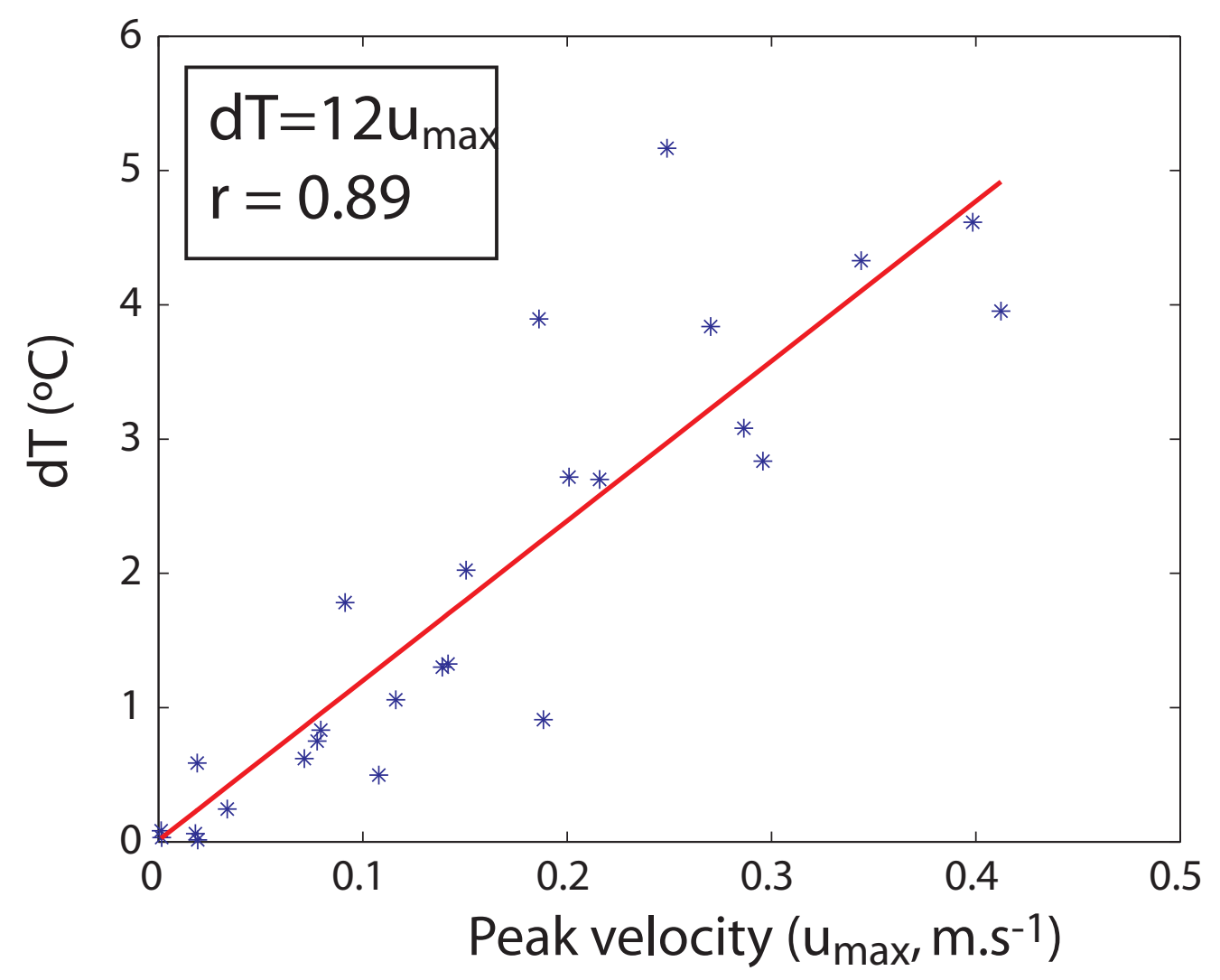


a) Alongshore flow

$\downarrow$

m.s $\mathrm{s}^{-1}$
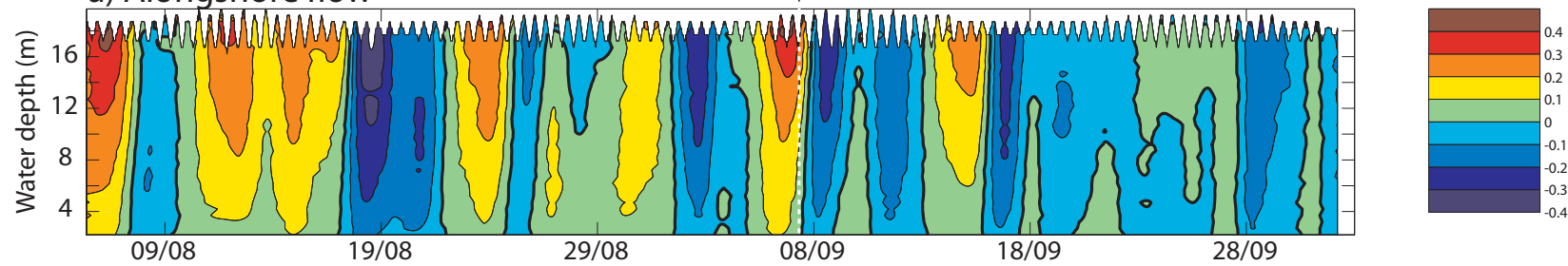

b) Cross shore flow

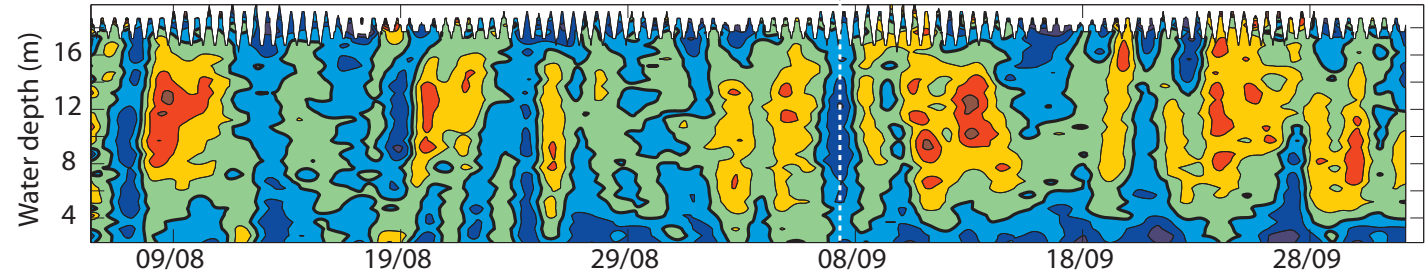

m.s-1
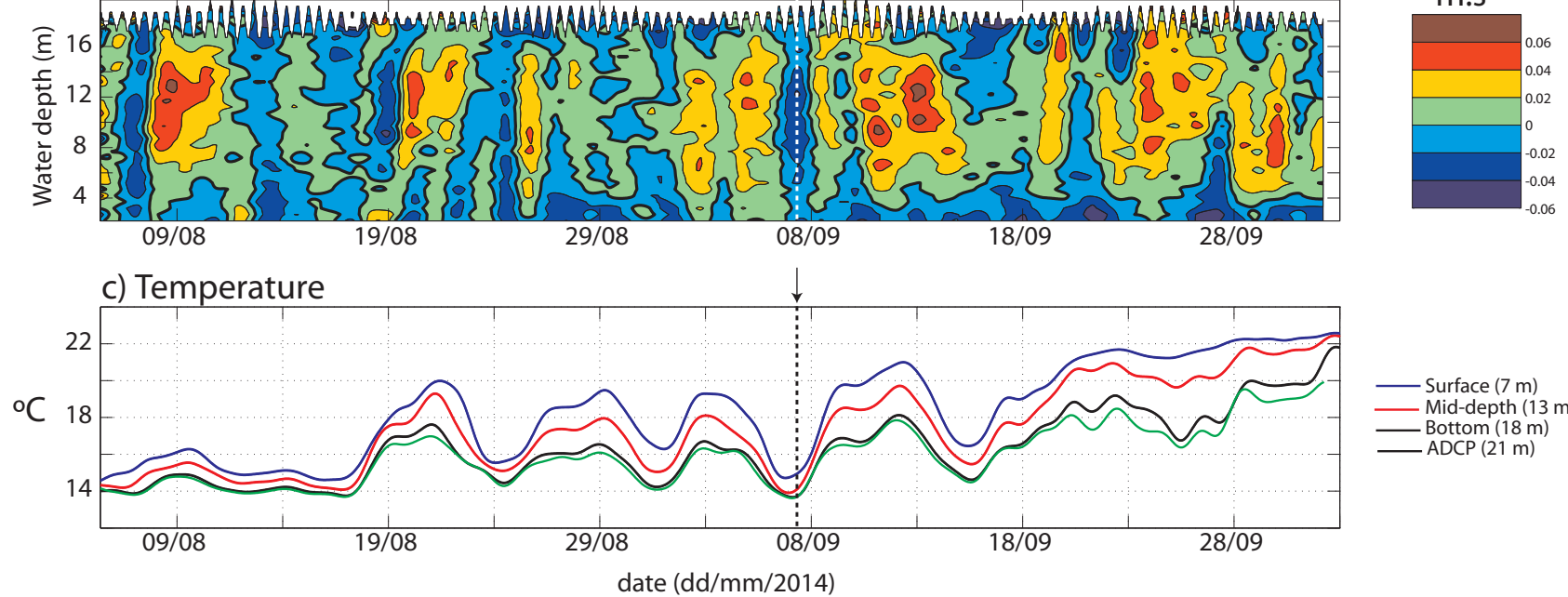

_ Surface (7 m) ADCP $(21 \mathrm{~m})$ 
Figure 9

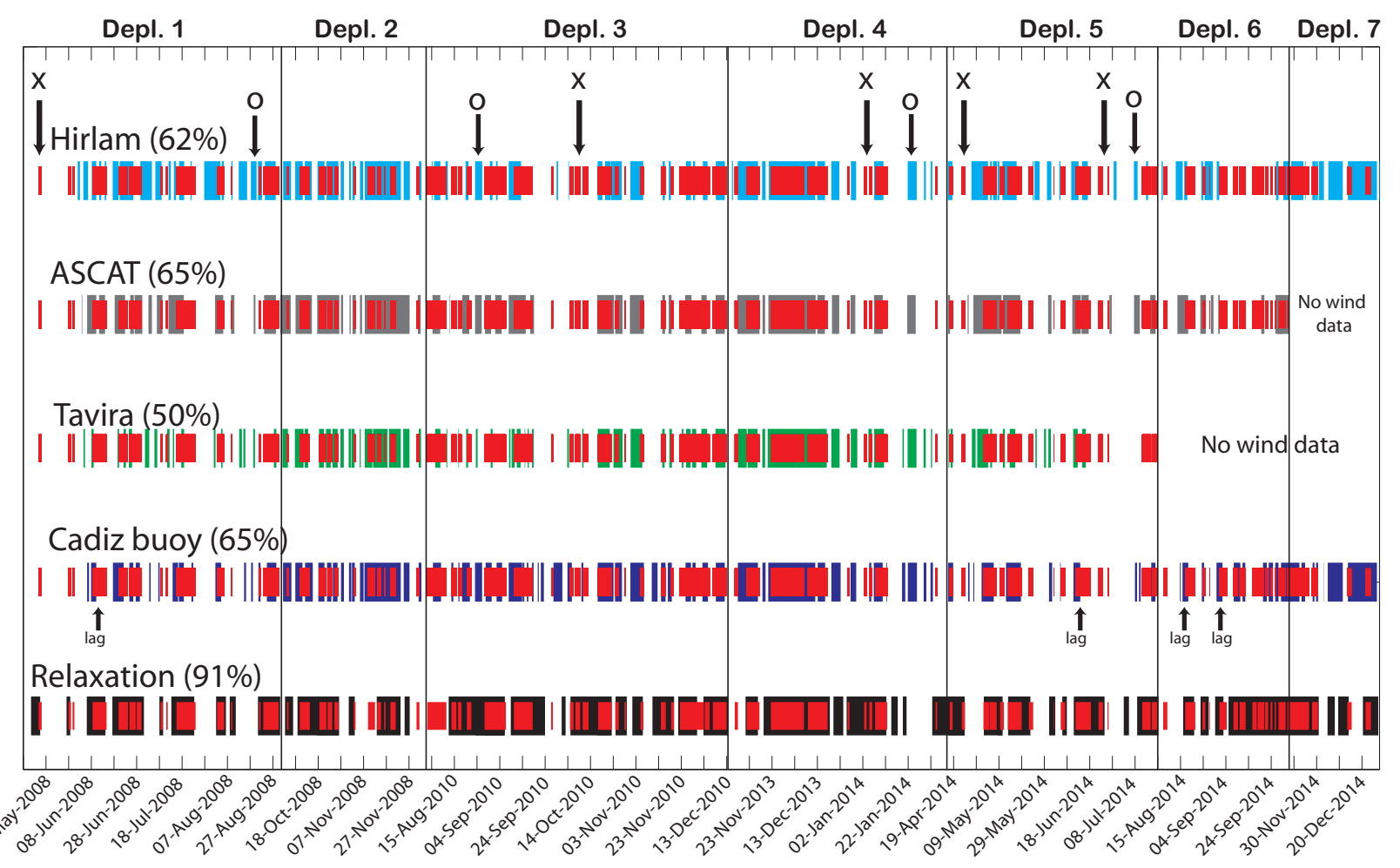


(a)
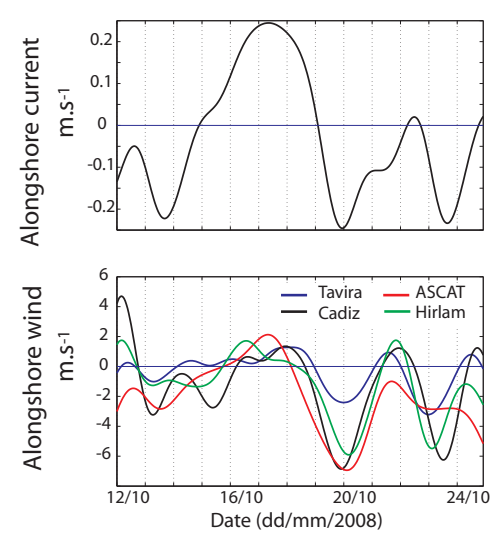

(b)
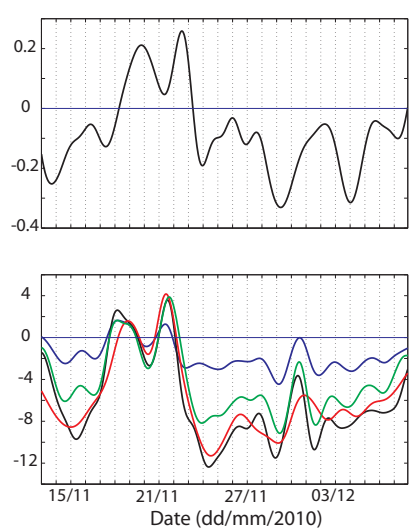

(c)
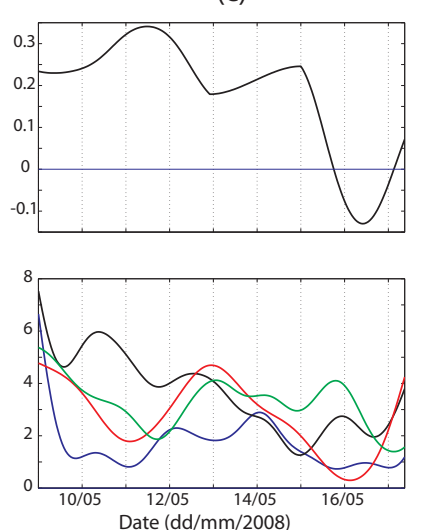

(d)
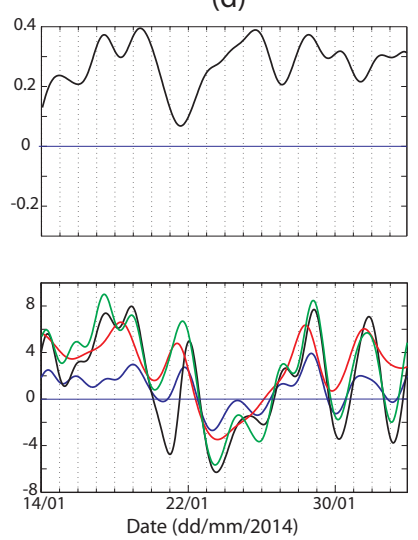
a) Energy $\mathrm{PC} 1\left(\mathrm{x} 10^{4}\right)$

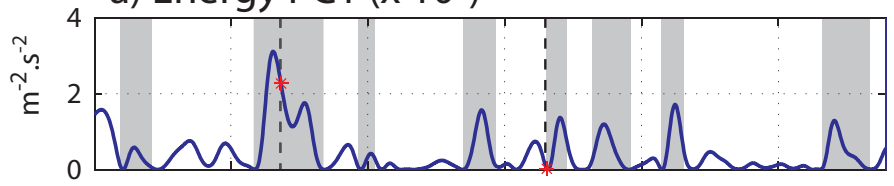

b) Energy PC2 (x 103)
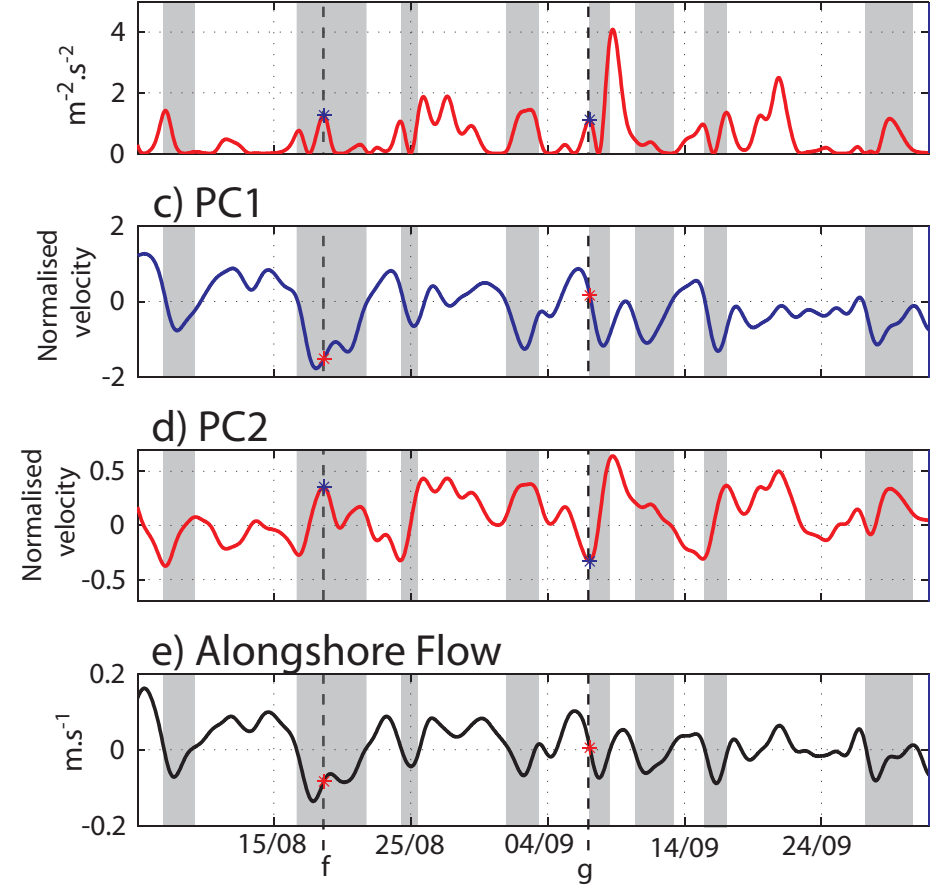

Date $(\mathrm{dd} / \mathrm{mm} / 2014)$
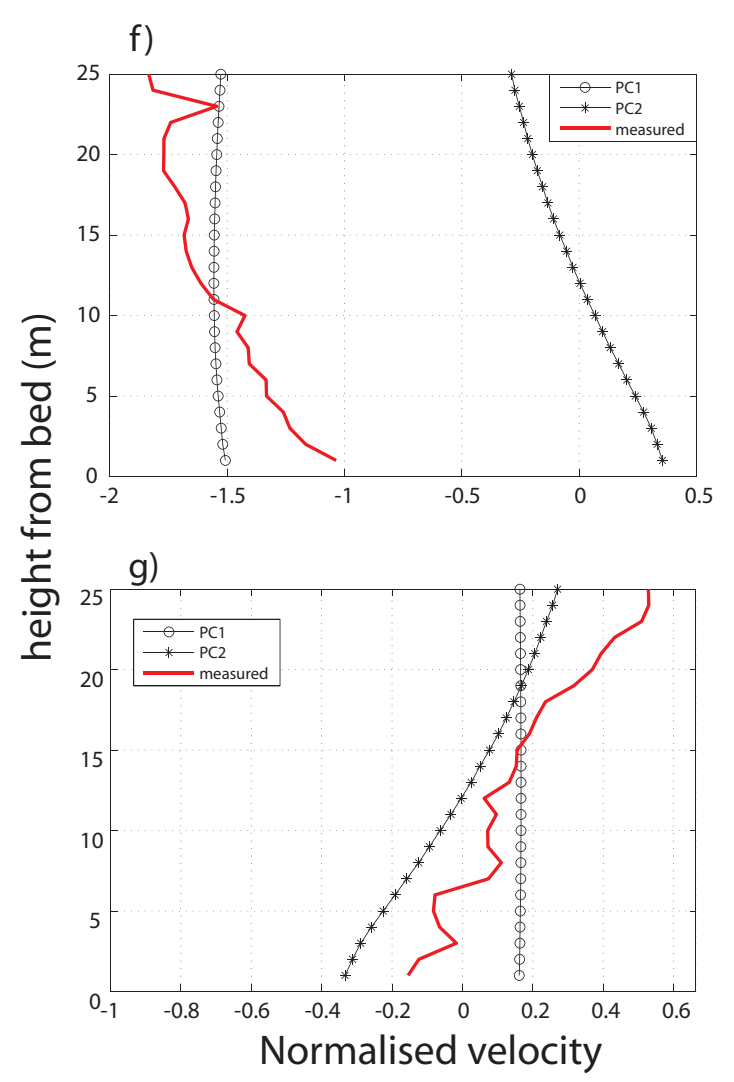

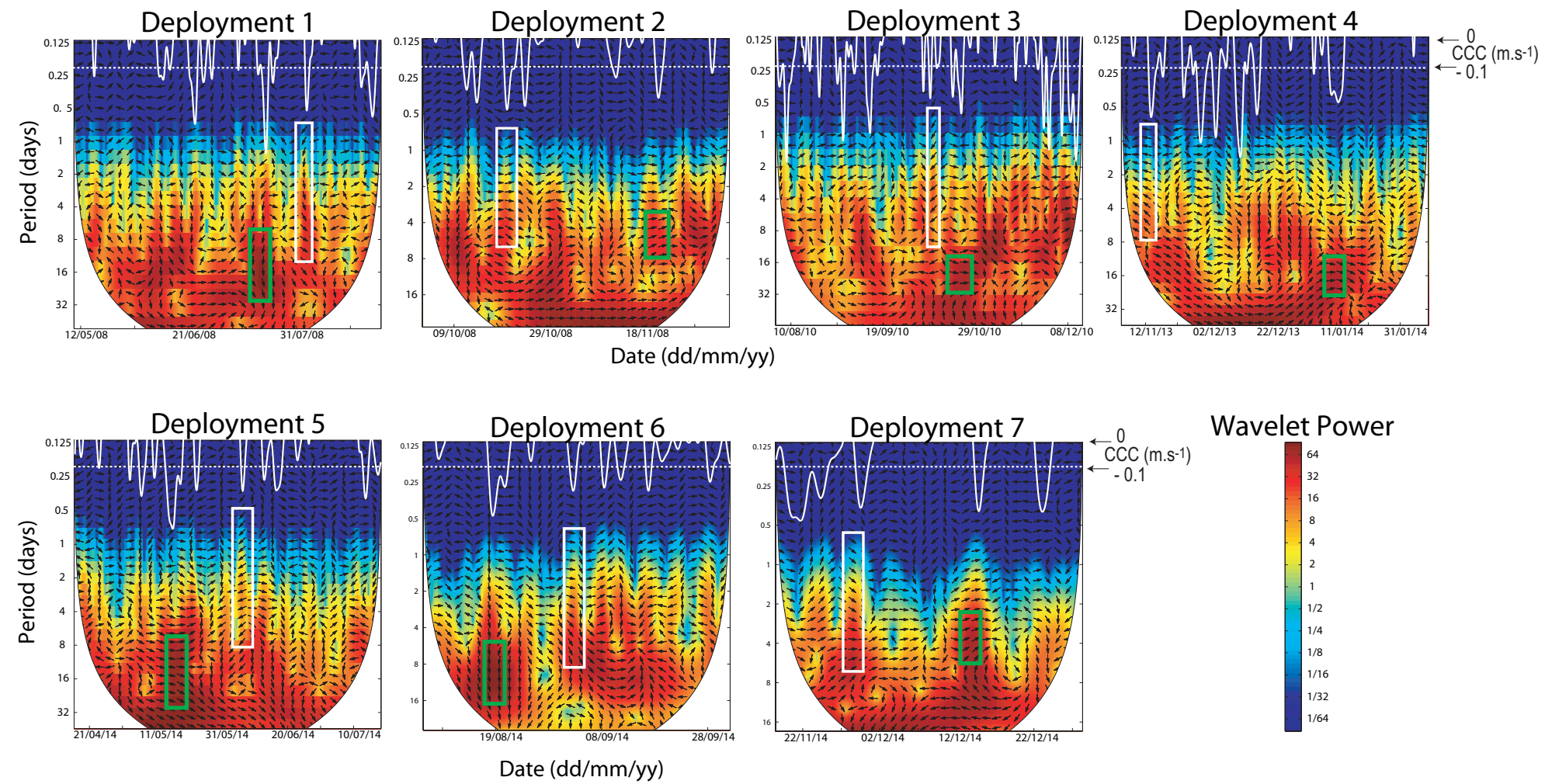

Wavelet Power

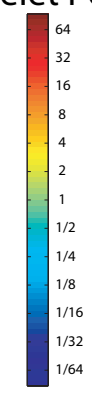


(a)

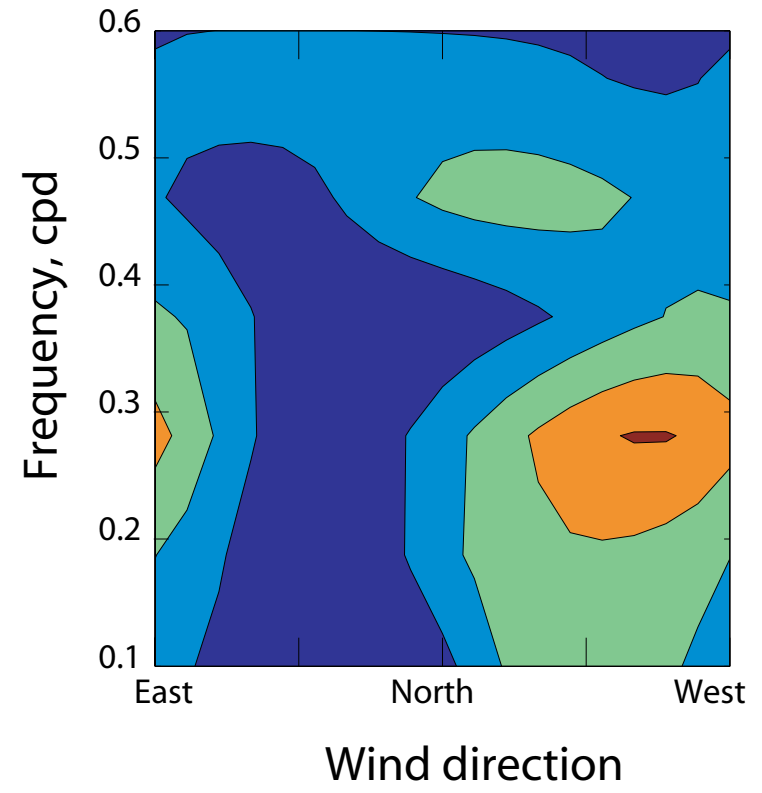

(b)

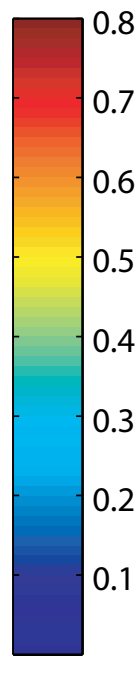
0.8

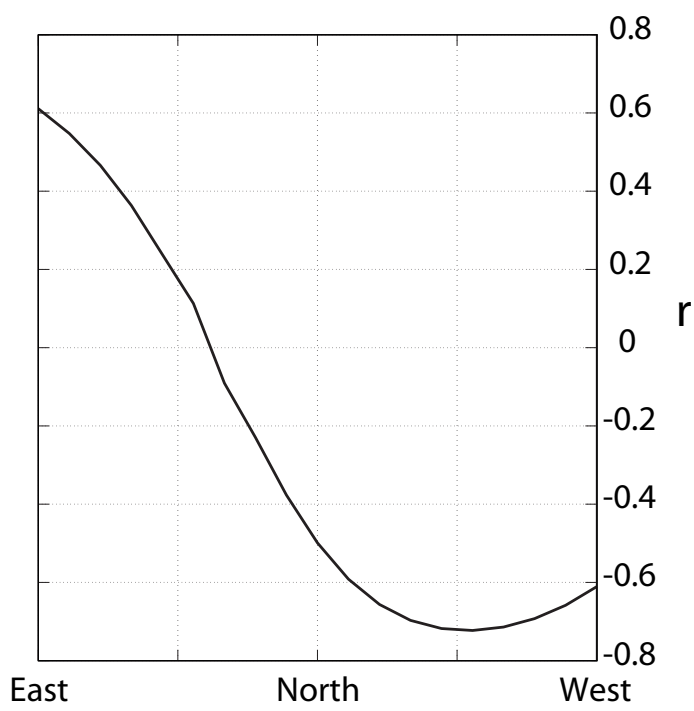

Wind direction 
Figure 15

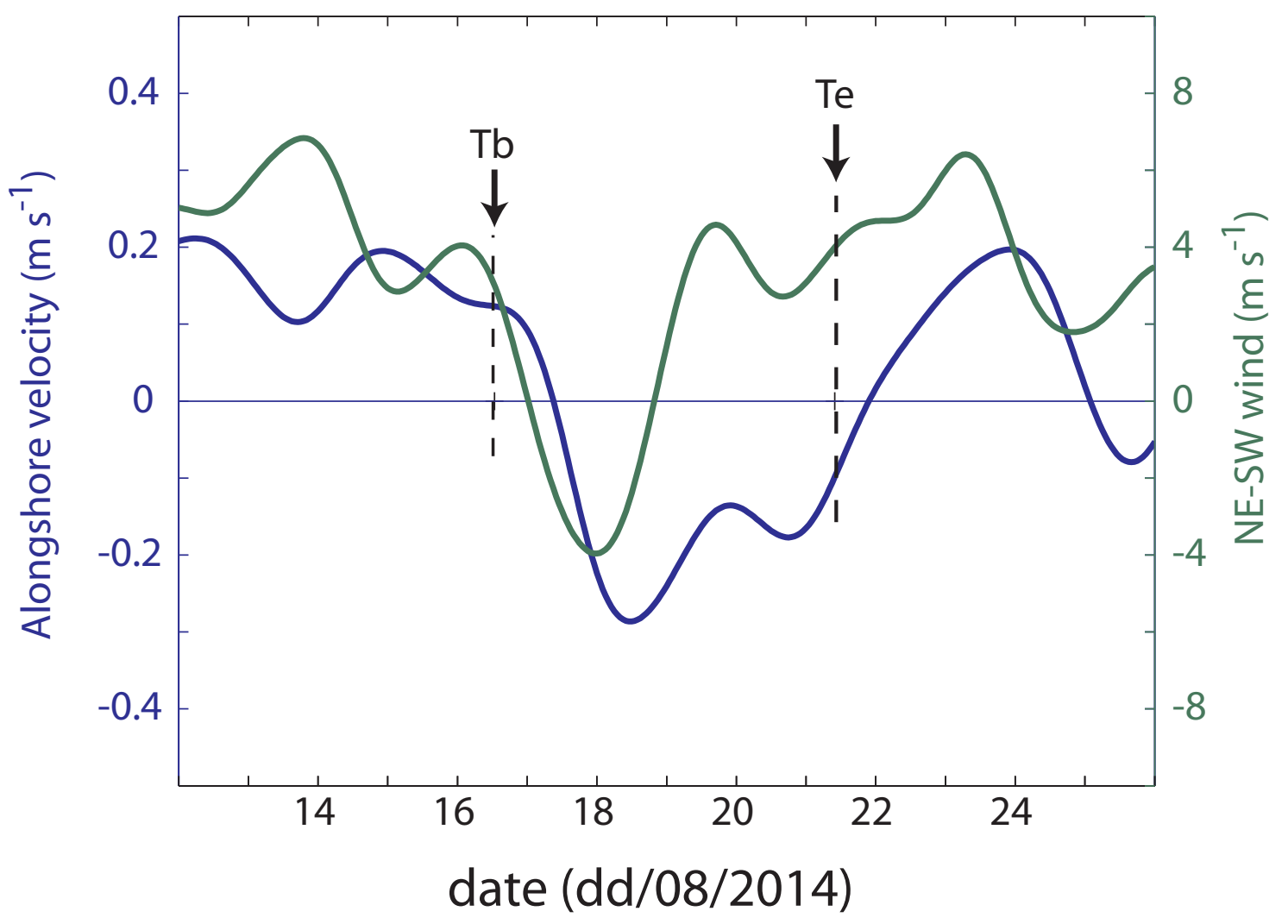

